\title{
Tipping the balance between necrosis and apoptosis in human and murine cells treated with interferon and dsRNA
}

\author{
M Kalai ${ }^{1}$, G Van Loo', T Vanden Berghe ${ }^{1}$, A Meeus ${ }^{1}$, \\ W Burm ${ }^{1}, X$ Saelens ${ }^{1}$ and $P$ Vandenabeele ${ }^{*, 1}$ \\ 1 Department of Molecular Biomedical Research, Unit of Molecular Signaling \\ and Cell Death, Flanders Interuniversity Institute for Biotechnology and Ghent \\ University, K.L. Ledeganckstraat 35, B-9000 Ghent, Belgium \\ * Corresponding author: P Vandenabeele, K.L. Ledeganckstraat 35, B-9000 \\ Ghent, Belgium. Tel.: 32-9-264-51-31; Fax: 32-9-264-53-48; \\ E-mail: peter.vandenabeele@dmb.rug.ac.be.
}

Received 24.8.01; revised 25.1.02; accepted 26.2.02

Edited by J Tschopp

\begin{abstract}
Interferons enhance the cellular antiviral response by inducing expression of protective proteins. Many of these proteins are activated by dsRNA, a typical by-product of viral infection. Here we show that type-I and type-II interferons can sensitize cells to dsRNA-induced cytotoxicity. In caspase-8or FADD-deficient Jurkat cells dsRNA induces necrosis, instead of apoptosis. In L929sA cells dsRNA-induced necrosis involves high reactive oxygen species production. The antioxidant butylated hydroxyanisole protects cells from necrosis, but shifts the response to apoptosis. Treatment with the caspase inhibitor benzyloxycarbonyl-Val-Ala-DLAsp(OMe)-fluoromethylketone or overexpression of $\mathrm{Bcl}-2$ prevent this shift and promote necrosis. Our results suggest that a single stimulus can initiate different deathsignaling pathways, leading to either necrotic or apoptotic cell death. Inhibition of key events in these signaling pathways, such as caspase activation, cytochrome $c$ release or mitochondrial reactive oxygen species production, tips the balance between necrosis and apoptosis, leading to dominance of one of these death programs.

Cell Death and Differentiation (2002) 9, 981-994. doi:10.1038/ sj.cdd. 4401051
\end{abstract}

Keywords: necrosis; apoptosis; dsRNA; interferon; caspase; reactive oxygen species

Abbreviations: Ac-DEVD-amc, acetyl-Asp(OMe)-Glu(OMe)-ValAsp(OMe)-aminomethylcoumarin; BHA, butylated hydroxyanisole; $\mathrm{CHX}$, cycloheximide; CrmA, cytokine responsemodifier A; DD, death domain; DHR123, dihydrorhodamine 123; FADD, Fas-associated death domain; GA, geldanamycin; hsp, heat-shock protein; IFN, interferon; $\mathrm{PI}$, propidium iodide; $\mathrm{PKR}$, interferon-inducible protein kinase; R123, rhodamine 123; RIP, receptor-interacting protein; ROS, reactive oxygen species; TB, Trypan blue; TLR, Toll-like receptor; TNF, tumor necrosis factor; ZDEVD-fmk, benzyloxycarbonyl-Asp-Glu-Val-Asp-fluoromethylketone; zVAD-fmk, benzyloxycarbonyl-Val-Ala-DL-Asp(OMe)-fluoromethylketone.

\section{Introduction}

Besides efficient production and spread of progeny, successful viral replication requires evasion of host defense mechanisms that limit replication or kill infected cells. However, infection by many viruses triggers not only immune and inflammatory responses, but also results in death of their cellular host. Infected cells warn other cells to protect themselves against an invading virus, mainly through the cytokines of the interferon (IFN) family. IFN promotes resistance to viral infection by inducing expression of many protective proteins, such as Mx proteins, IFN-inducible protein kinase (PKR) and enzymes of the 2-5A synthetase/RNase $L$ pathway. ${ }^{1,2}$ The latter two systems mainly target viral RNA and its translation, and were shown to be important for the resistance and clearance of viruses. Although IFNs induce the production of proteins needed for cellular antiviral response, they usually do not activate them. The trigger activating many of these proteins, including PKR and 2-5A synthetases, seems to be the presence of viral dsRNA. Indeed, most viruses promote the synthesis of dsRNA at some time during their replication cycle. ${ }^{3}$ Viral dsRNA, released from dying infected cells, may act as a signal warning for infection. dsRNA is a strong inducer of inflammation, promoting activation of the nuclear factor $\kappa \mathrm{B}^{4,5}$ and production of inflammatory cytokines. ${ }^{3,6}$ A recent report demonstrated that the innate immune-recognition Toll-like receptor (TLR) 3 recognizes dsRNA and induces, after activation, cytokine production through an MyD88-dependent signaling pathway. ${ }^{7}$ Both synthetic and viral dsRNA were shown to lead to cell death. ${ }^{5,8,9}$ IFNs have been suggested to potentiate virusinduced apoptosis by initiating the Fas-associated death domain (FADD)/caspase-8 death-signaling pathway in a dsRNA-dependent way by activating PKR. ${ }^{10-12}$ Overexpression and activation of either PKR or RNase $L$ promote apoptosis. ${ }^{10,13-15}$ Another mechanism implicated in protection against viral infections is the production of reactive oxygen species (ROS). Indeed, HIV and hepatitis B infections induce ROS production in infected cells. ${ }^{16}$

ROS production was reported to occur both in apoptosis and necrosis. ${ }^{17-19}$ Apoptosis avoids proinflammatory spilling of the cellular content into the surrounding tissue. In vivo, apoptotic cells are rapidly engulfed in a process that is considered immunologically silent. ${ }^{20}$ Apoptotic cells reduce their volume by pumping out ions and organic osmolytes, and contracting and reorganizing the cytoskeleton. The process involves nuclear condensation, DNA degradation and blebbing of the plasma membrane. Among the players best characterized in the apoptotic machinery are cysteine aspartate-specific proteases called caspases. ${ }^{21}$ Necrosis is characterized by cellular swelling leading to burst of the plasma membrane and release of the cytosolic contents to the surrounding tissue, causing inflammation. The generation of an appropriate immune 
response during apoptotic and necrotic damage may be critical for either antitumor or antiviral responses. ${ }^{5,22-24}$ In apoptosis and necrosis, events occurring in the mitochondria were shown to play a major role in the cell-killing process. $^{18,25,26}$ Originally, necrosis was regarded as a disordered mode of cell death, resulting from severe and acute injuries under conditions where apoptosis could not take place for some reason. However, studies have demonstrated that necrosis can also occur in normal cell physiology and embryonic development ${ }^{27}$ as well as in ischemia-reperfusion damage. ${ }^{28}$ The fact that members of the tumor necrosis factor (TNF) family can induce necrotic cell death in certain cells and cellular conditions, further supports the idea that a necrotic-like cell death pathway, controlled by a particular intrinsic death program (distinct from apoptosis), really exists. ${ }^{18,28-36}$

In the present study we determined the type of death induced in human and murine cells by IFNs, dsRNA and their combination, compared death with that induced by TNF and anti-Fas treatment, and investigated whether ROS production and proteins, such as caspases, FADD and the death domain (DD)-containing receptor-interacting protein (RIP), play a role in the process. Our results show that IFNs can sensitize cells to dsRNA-induced apoptosis or necrosis. We demonstrate that a single stimulus, be it dsRNA or anti-Fas, can initiate different cell death pathways, leading either to necrosis or to apoptosis. We show that the availability of certain proteins, caspase activation and events in the mitochondria, such as elevated production of ROS or release of cytochrome $c$, can determine whether a cell will die by necrosis or by apoptosis. Our results suggest that IFN- and dsRNAinduced necrosis may play a role, besides apoptosis, in cellular antiviral responses and pathologies.

\section{Results}

\section{dsRNA can induce caspase-8- and FADD- dependent, as well as caspase-8- and FADD- independent cell death in human Jurkat cells}

Jurkat $E$ cells respond to anti-Fas by rapid apoptosis. However, JB6 cells derived from Jurkat E (which lack caspase-8 and overexpress $\mathrm{Bcl}-2$ ) are resistant to antiFas-induced apoptosis. ${ }^{29,36}$ We tested the response of both cell lines to anti-Fas and to a $24 \mathrm{~h}$ pretreatment with either IFN- $\alpha$ or IFN- $\gamma$, followed by a challenge with dsRNA. Light microscopy revealed that Jurkat $\mathrm{E}$ cells died by antiFas-induced apoptosis, whereas JB6 did not die (Figure $1 \mathrm{~A})$. Both cell lines died in response to dsRNA (Figure $1 A, B)$. However, the morphology of the dying cells differed. Jurkat $\mathrm{E}$ died with typical apoptotic appearance, whereas JB6 responded by necrosis. The cells rounded up and were swelling. The cytoplasm cleared and the content concentrated around the nucleus (Figure 1A). The response of JB6 cells was stronger and faster than that of Jurkat $E$ (Figure $1 B, C$ ). IFNs were not cytotoxic by themselves and increased the sensitivity of cells to dsRNA only slightly, without changing the cell death morphology of either cell line (data not shown). To ensure that
dsRNA-induced cell death occurred directly and did not require de novo protein synthesis, cells were untreated or pretreated with $10 \mu \mathrm{g} / \mathrm{ml}$ of the translation inhibitor cycloheximide $(\mathrm{CHX})$ before a challenge with dsRNA (Figure 1B). Pretreatment with $\mathrm{CHX}$ did not protect cells from dsRNA-induced cytotoxicity and even increased the response of Jurkat $E$ cells (Figure 1B). These results suggest that both dsRNA-induced apoptosis and necrosis do not require de novo protein synthesis.

Previous reports demonstrated that dsRNA-induced cell death occurs by caspase activation. ${ }^{10-12}$ Therefore, we tested whether caspases were activated in Jurkat cells during dsRNA-induced cell death and whether treatment with caspase inhibitors protected these cells form death. An increase in DEVDase activity was detected only in Jurkat $E$ cells treated with either dsRNA or anti-Fas (Figure 1C). Pretreatment of Jurkat $E$ with the pan-caspase inhibitor benzyloxycarbonyl-Val-Ala-DL-Asp(OMe)-fluoromethylketone (zVAD-fmk) protected cells from anti-Fas-induced apoptosis, whereas the caspase- 3 and caspase-7 inhibitor benzyloxycarbonyl-Asp(OMe)-Glu(OMe)-Val-DL-Asp(OMe)fluoromethylketone (zDEVD-fmk) only slightly decreased the apoptotic response (Figure 1D). By contrast, the inhibitors did not at all affect the level of cell death observed with dsRNA in both cell lines (Figure 1D). These results suggest that, although dsRNA can induce apoptosis in certain cells and conditions, as observed with Jurkat E, it can also kill cells without caspase activation, as observed with Jurkat E+zVAD-fmk and the caspase-8-deficient Bcl-2overexpressing JB6.

It has previously been reported that treatment with IFN$\alpha / \beta$ greatly sensitizes fibroblasts to FADD-dependent apoptosis in response to a dsRNA treatment or influenza virus infection. ${ }^{12}$ Many reports showed that the FADD/ caspase-8 pathway is required for DD receptor-mediated apoptosis. ${ }^{37-39}$ However, several recent reports demonstrated that necrosis could also be initiated by FADD. ${ }^{29,33,36}$ To further explore the role of caspase- 8 and FADD in dsRNA-induced apoptosis and necrosis we tested the response of caspase-8-deficient (J9.2) and FADD-deficient (J2.1) Jurkat cells to dsRNA and IFN$\gamma^{37,40}$ In contrast to their parental cells (JA3), caspase-8and FADD-deficient cells were completely resistant to antiFas-induced cell death (Figure 2A). All three cell lines were resistant to dsRNA-induced cytotoxicity unless pretreated with IFN (Figure 2A). However, J9.2 and J2.1 cells were more sensitive to IFN+dsRNA-induced cell death than their parental JA3 cells. Light microscopy and DEVDase activity measurements showed that the parental cells responded by apoptosis, while the caspase-8- and FADD-deficient cells died by necrosis (Figure 2B). These results demonstrate that both caspase-8 and FADD are not needed for dsRNA-induced necrosis and suggest that their removal shifts the response from apoptosis to necrosis. Overexpression of dominant-negative FADD sensitizes cells to TNF-induced cytotoxicity. ${ }^{32,33}$ FADDdeficient $T$ cells have also been shown to be resistant to TRAIL and Fas ligand-induced caspase-independent death, but not to TNF-induced necrosis. ${ }^{34}$ JA3 and caspase-8-deficient $\mathrm{J} 9.2$ cells failed to respond to TNF, 
A
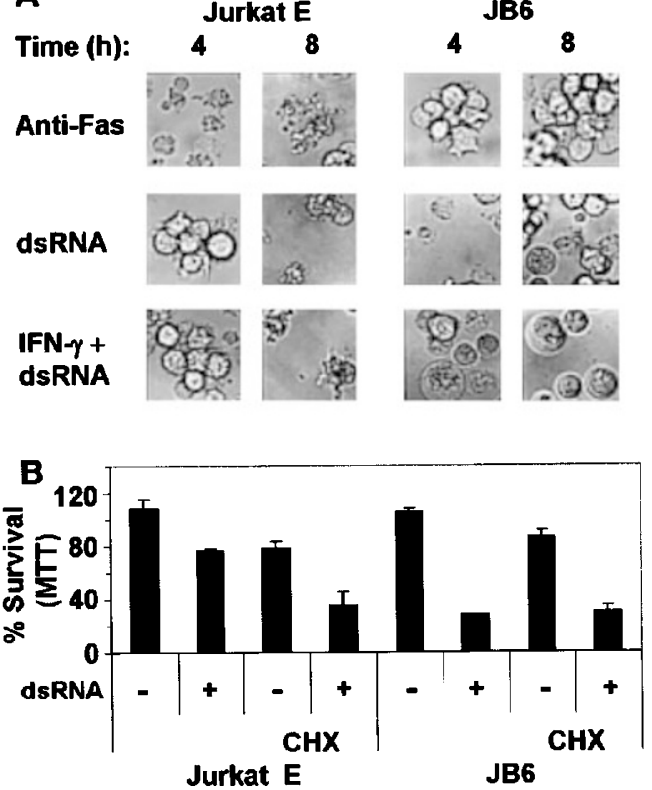

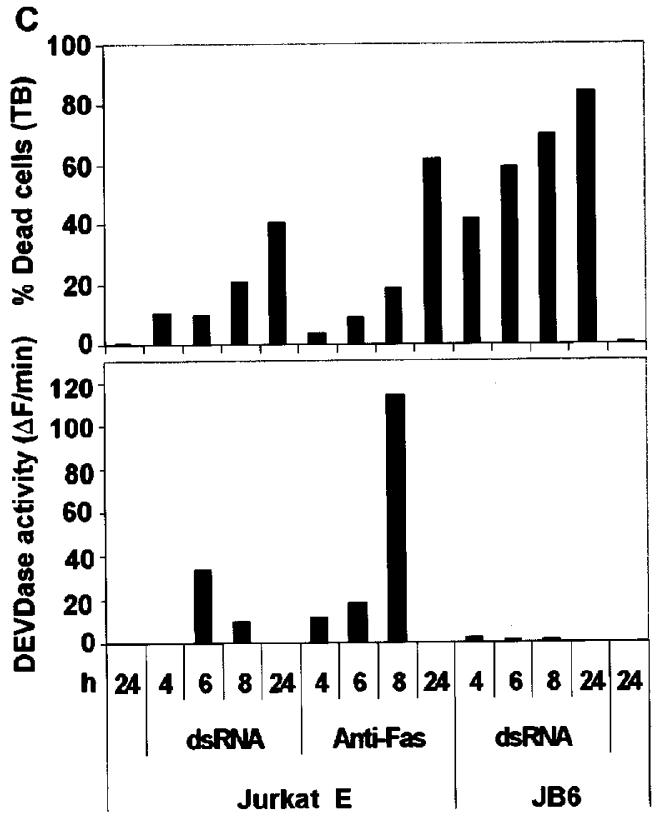

Jurkat E

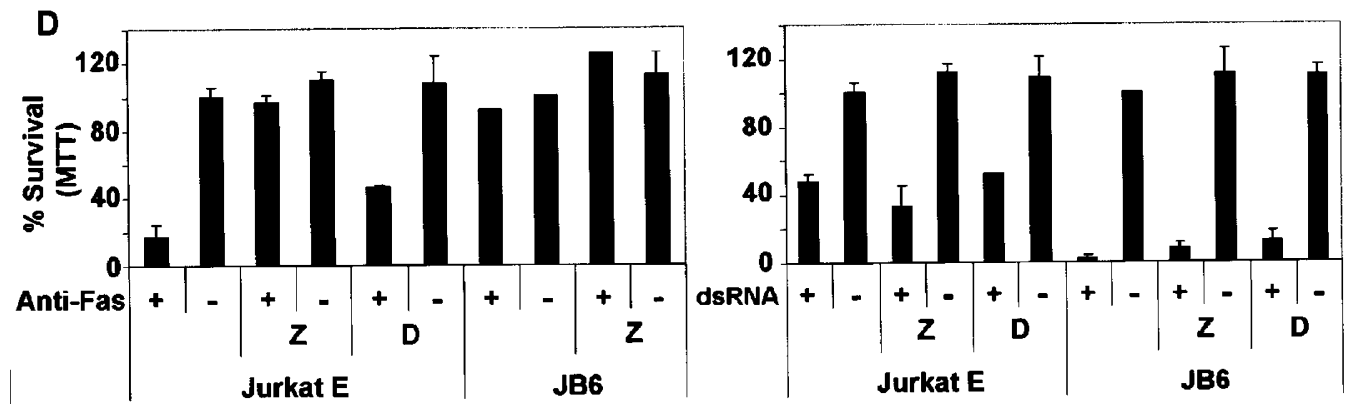

Figure 1 Treatment with dsRNA induces both caspase-dependent and caspase-independent cell death in human Jurkat cells. (A) Light microscopy of cells dying in response to dsRNA $(100 \mu \mathrm{g} / \mathrm{ml})$, with or without IFN- $\gamma(1000 \mathrm{IU} / \mathrm{ml})$. Death of Jurkat E cells resembles apoptosis induced with $100 \mathrm{ng} / \mathrm{ml}$ anti-Fas. JB6 cells are resistant to anti-Fas-induced apoptosis and respond to dsRNA by necrosis. (B) dsRNA-induced cell death does not depend on de novo protein synthesis. Cytotoxicity of $100 \mu \mathrm{g} / \mathrm{ml}$ dsRNA in the presence or absence of $10 \mu \mathrm{g} / \mathrm{ml}$ of the mRNA translation inhibitor CHX. (C) Caspase activation occurs in cell death induced with $30 \mathrm{ng} / \mathrm{ml}$ anti-Fas and $100 \mu \mathrm{g} / \mathrm{ml}$ dsRNA in Jurkat E, but not in JB6 cells. Nevertheless, the latter die more rapidly than the former in response to dsRNA. Loss of membrane integrity as a measure for cell death was determined as fractions stained by Trypan blue (TB). Caspase activity was measured by Ac-DEVD-amc cleavage. (D) Caspase inhibitors delay or inhibit Fas-mediated apoptosis, but not dsRNA-induced cell death. Cells were preincubated for 60 min with $50 \mu \mathrm{M}$ of zVAD-fmk (Z) or ZDEVD-fmk (D) before addition of anti-Fas $(30 \mathrm{ng} / \mathrm{ml})$ or dsRNA $(100 \mu \mathrm{g} / \mathrm{ml})$

even at high concentrations, and FADD-negative J2.1 cells responded clearly by necrosis (data not shown). This again demonstrates that although necrosis can be initiated by FADD, the latter is not required for initiating the necrotic-signaling pathway by dsRNA or TNF.

It has also been shown that pretreatment with geldanamycin (GA), an anti-cancer drug and inhibitor of the chaperone heat-shock protein (hsp) 90 , or RIP deficiency protect Jurkat cells from DD receptor-induced necrosis. ${ }^{34}$ We tested the effect of pretreatment of JE and JB6 cells with GA on their response to dsRNA. Treatment with GA alone did not affect the viability of JB6 cells (Figure 3A), However, GA protected these cells from dsRNA-induced necrosis. Moreover, GA induced Jurkat E to die by apoptosis and intensified their apoptotic response to dsRNA (Figure 3A). GA was previously shown to decrease the concentration of RIP in Jurkat cells, and RIP deficiency was reported to protect these cells from necrosis mediated by TRAIL receptor-2, Fas and TNF receptor-1. ${ }^{34,41}$ Therefore, we tested the response of RIPdeficient Jurkat cells ${ }^{42}$ to dsRNA and IFN- $\gamma$. Only RIPpositive cells responded to dsRNA following pretreatment with IFN, though both cell lines failed to respond to dsRNA alone. Moreover, RIP-positive cells died in response to IFN+dsRNA also after pretreatment with zVAD-fmk, while RIP-negative cells remained resistant; this suggests that both the apoptotic and necrotic signaling pathways initiated by dsRNA are affected by the lack of RIP (Figure 3B). Both RIP-positive and RIP-negative cells responded by apoptosis to an anti-Fas treatment and were protected from death by zVAD-fmk (Figure 3B). This demonstrates that the lack of response to dsRNA in RIP-deficient cells did not arise from a dysfunction in their apoptotic machinery. 

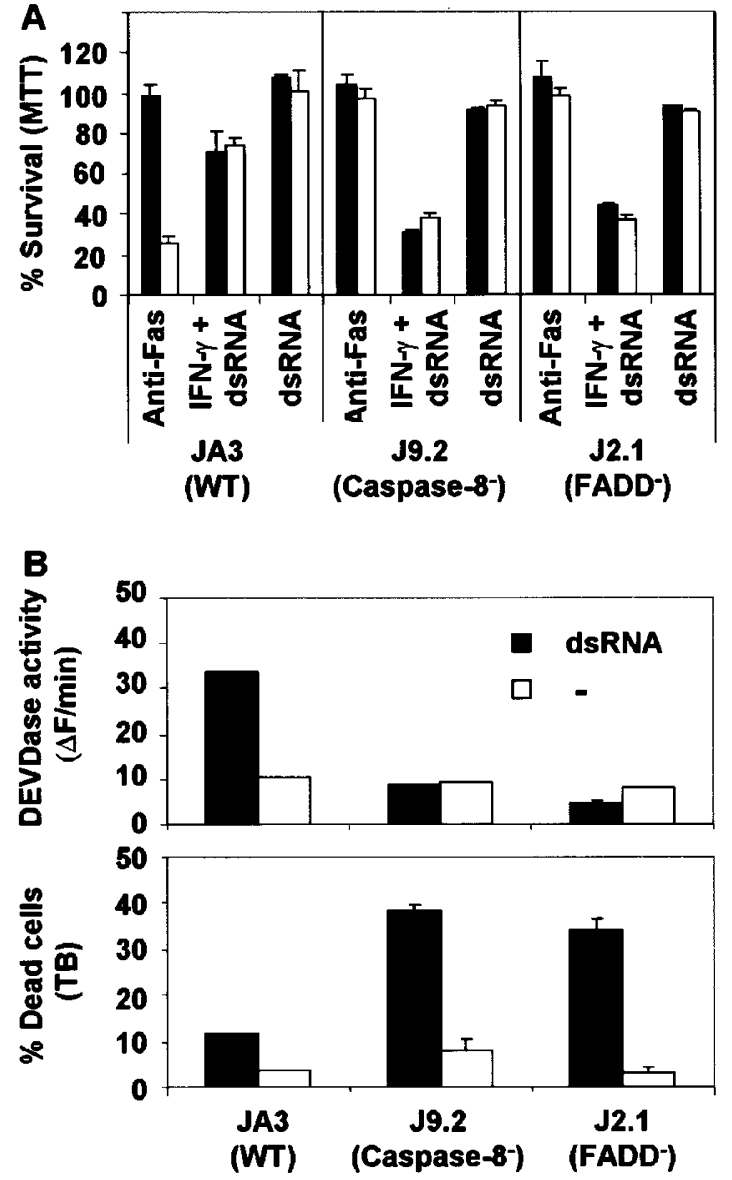

Figure 2 FADD and caspase-8-deficient Jurkat cells respond to IFN+dsRNA by necrosis, whereas their parental JA3 cells die by apoptosis. (A) Cytotoxicity with (filled boxes) and without (open boxes) zVAD-fmk $(25 \mu \mathrm{M})$ of Anti-Fas $(30 \mathrm{ng} / \mathrm{ml})$, dsRNA $(100 \mu \mathrm{g} / \mathrm{ml})$ or dsRNA $(100 \mu \mathrm{g} / \mathrm{ml})+\mathrm{IFN}-\gamma(1000 \mathrm{IU} / \mathrm{ml})$. (B) Caspase activation occurs in parental JA3, but not in caspase-8-deficien

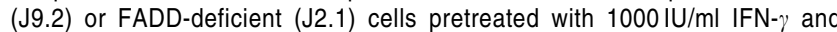
induced to die with $100 \mu \mathrm{g} / \mathrm{ml}$ dsRNA. Caspase activity was measured by AcDEVD-amc cleavage and loss of membrane integrity was determined by TB staining following $6 \mathrm{~h}$ of dsRNA treatment

Pretreatment of murine L929sA cells with type-I or type-II IFNs, followed by a challenge with dsRNA, leads to necrosis in a TNF-independent manner

L929sAFas cells die by necrosis when treated with TNF, and respond by apoptosis to an anti-Fas treatment. ${ }^{30,31}$ We tested the sensitivity of these cells to dsRNA killing with or without 24-h pretreatment with type-I or type-II IFNs. IFN or dsRNA alone were not cytotoxic, but a combination of IFN with dsRNA killed the cells efficiently in a synergistic manner. The level of cytotoxicity depended on the concentration of dsRNA and IFN used (Figure 4A). Light microscopy revealed that the dying cells had a necrotic morphology (Figure 4B). The same type of response was observed with all IFNs tested, though the response was the strongest with IFN- $\beta$ (Figure 4A).

IFN and dsRNA may induce expression of TNF and Fas ligand, and of their receptors. ${ }^{12,43,44}$ Therefore death may occur in an indirect way. Pretreatment of L929sAFas with IFNs had no effect on Fas-mediated apoptosis, whereas
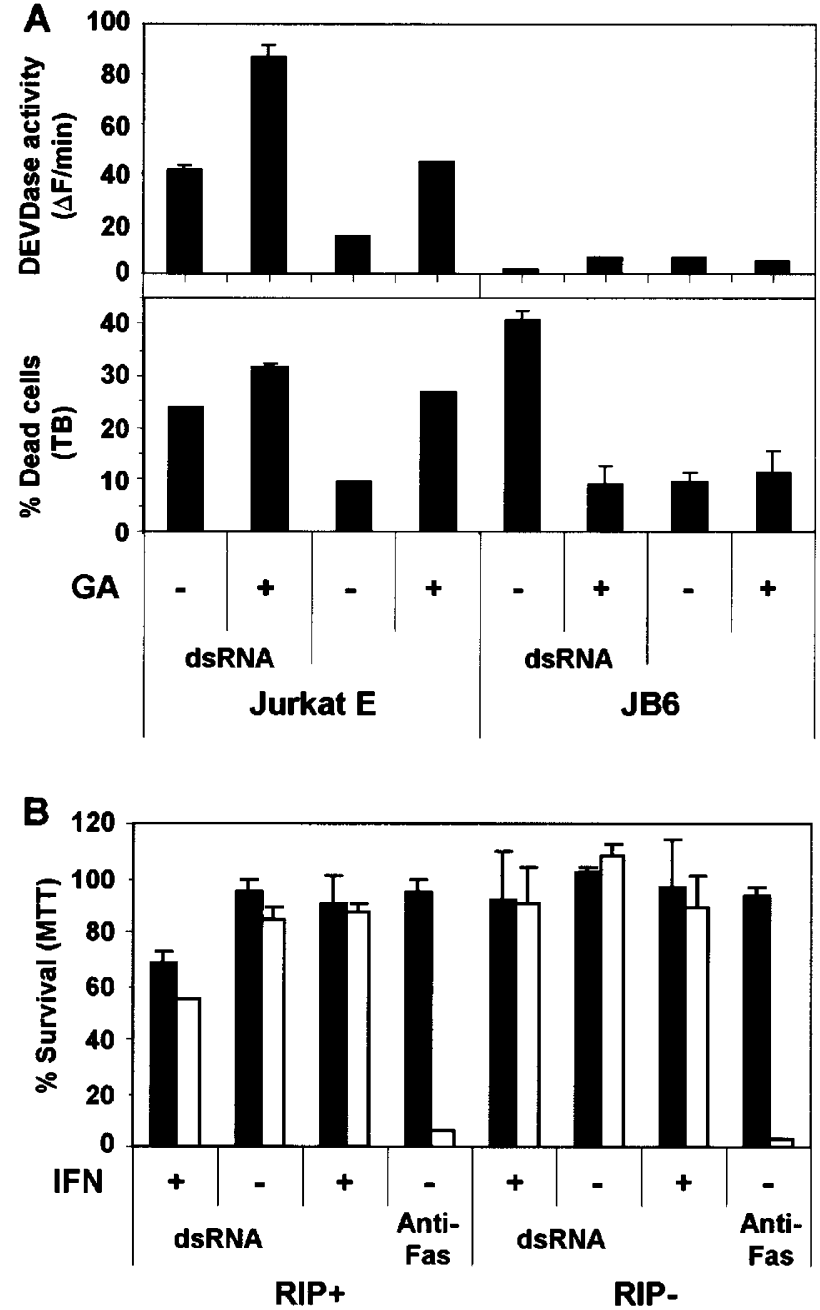

Figure 3 Effect of inhibition of hsp-90 or RIP deficiency on dsRNA-induced cell death. (A) Cells were treated for $24 \mathrm{~h}$ with the hsp-90 inhibitor GA (100 nM) and then induced to die for $6 \mathrm{~h}$ with dsRNA $(100 \mu \mathrm{g} / \mathrm{ml})$. (B) The cytotoxicity of dsRNA $(100 \mu \mathrm{g} / \mathrm{ml}), 1000 \mathrm{IU} / \mathrm{ml} \mathrm{IFN}-\gamma$ and their combination was tested on RIP-positive and RIP-negative Jurkat cells with (filled boxes) and without (open boxes) zVAD-fmk $(25 \mu \mathrm{M})$. Treatment with anti-Fas $(30 \mathrm{ng} / \mathrm{ml})$ was used as a control

IFN- $\gamma$, but not IFN- $\beta$, increased their sensitivity to TNFinduced necrosis (data not shown). To ensure that the cell death observed with IFN+dsRNA did not arise from endogenously expressed TNF and TNF receptors we repeated the experiments in the presence of anti-TNFneutralizing antiserum (Figure $4 \mathrm{C}$ ). The antibodies blocked death induction by TNF, but failed to affect the cytotoxicity of type-I or type-II IFNs+dsRNA. Control serum had no effect on both. Similar results were obtained with TNF-resistant L929r1 cells (Figure 4C). Hence IFNs can sensitize cells to dsRNA-induced necrosis in a TNF-independent manner.

\section{Butylated hydroxyanisole (BHA) shifts the response to a treatment with IFN- $\beta+$ dsRNA from necrosis to apoptosis}

Induction of ROS production occurs both in apoptosis and necrosis, and was suggested to play a crucial role in the 

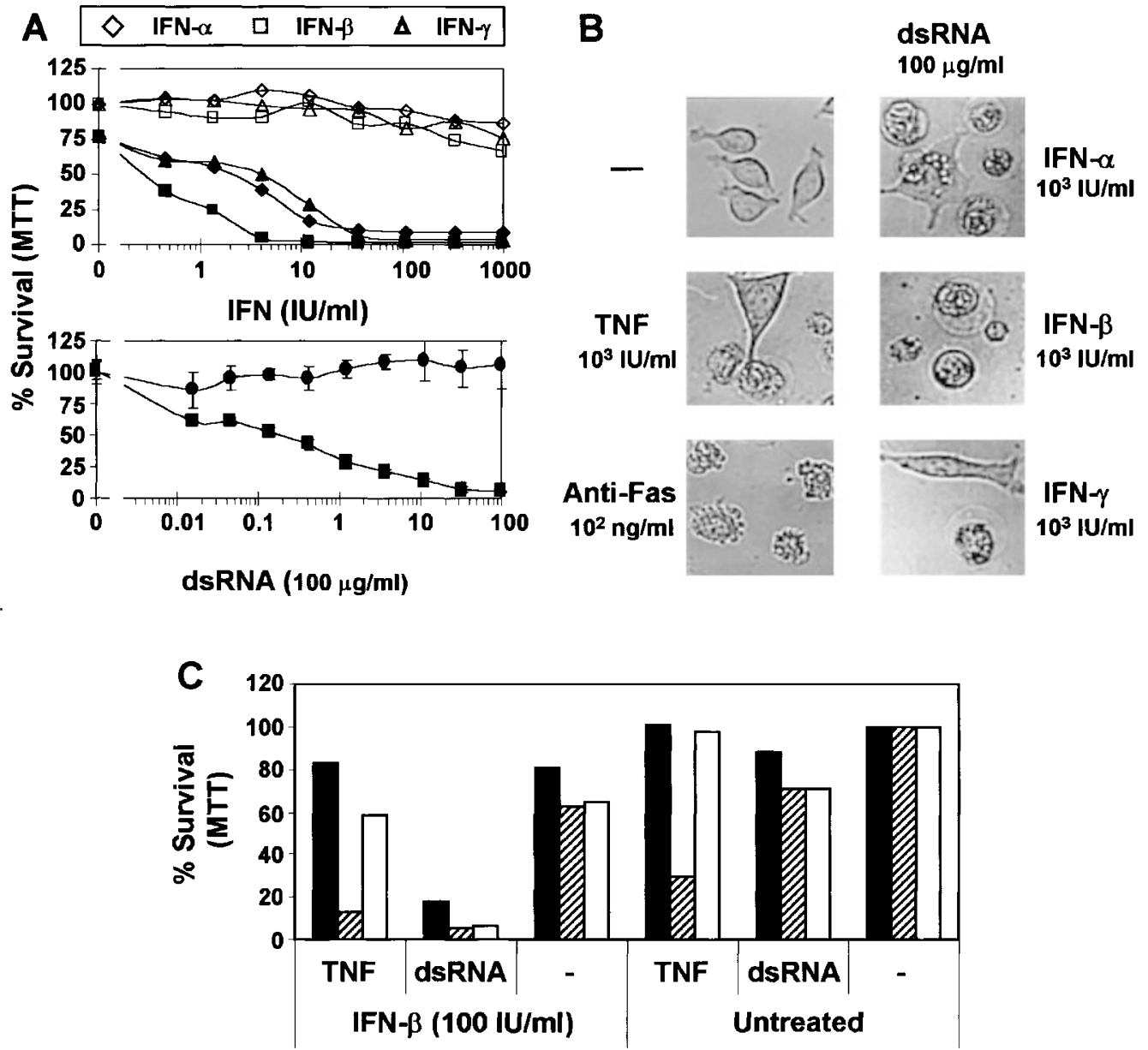

Figure 4 Type-I and type-II IFNs prime murine L929sA cells to dsRNA-induced necrosis. (A) IFN- $\alpha$, IFN- $\beta$ and IFN- $\gamma$ prime cells to dsRNA toxicity. The effect depends on the concentration of dsRNA and IFN used. Top, with (filled boxes) and without (open boxes) dsRNA (100 $\mu \mathrm{g} / \mathrm{ml})$; bottom, with (squares) and without (circles) IFN- $\beta(200 \mathrm{IU} / \mathrm{ml})$. (B) Light microscopy of L929sAFas cells. Cell death induced by IFN+dsRNA resembles TNF-induced necrosis and not Fas-mediated apoptosis. (C) IFN- and dsRNA-induced necrosis is not mediated by endogenous p55 TNF receptor. TNF-resistant L929r1 cells (filled bars) were treated with TNF or dsRNA with or without IFN. TNF-sensitive L929sA cells were treated similarly, but with addition of control (dashed bars) or anti-TNF-neutralizing antisera (white bars). Results obtained with all three IFNs were similar (only those of IFN- $\beta$ are shown)

cellular death process. Although several possible sources for this ROS production were reported in cell death signaling, the mitochondria were shown to be the main producers. ${ }^{17-19,25}$ In L929sA cells, TNF induces oxidative stress and ROS production in the mitochondria. Antioxidants like BHA can inhibit ROS production by TNF and block its cytotoxicity. Hence, ROS are essential for TNF-induced necrosis. ${ }^{17,30} \mathrm{We}$ tested the effect of BHA on the cytotoxicity and ROS generation by treatment with IFN- $\beta+$ dsRNA or TNF+LiCl, a treatment previously shown to increase the sensitivity of cells to TNF-induced cytotoxicity ${ }^{45}$ (Figure 5). Both treatments induced ROS production in propidium iodide $(\mathrm{PI})$-negative cells that kept their membrane integrity, demonstrating that ROS preceded cell death (Figure 5A). However, BHA was more efficient in blocking ROS in response to $\mathrm{TNF}+\mathrm{LiCl}$ than in response to IFN- $\beta+$ dsRNA. Addition of BHA inhibited the cytotoxicity of TNF+LiCl, but did not affect that of anti-Fas (Figure 5B). Cell death rates obtained with IFN- $\beta+$ dsRNA and anti-Fas were similar. Both occurred more rapidly than with $\mathrm{TNF}+\mathrm{LiCl}$ (Figure 5B). BHA delayed death after IFN- $\beta+$ dsRNA treatments, but the protective effect measured by the absence of $\mathrm{PI}$ staining disappeared completely within $6 \mathrm{~h}$ (Figure $5 \mathrm{~B}$ ). Controls of BHA, BHA+IFN- $\beta$, or BHA+dsRNA treatments were not cytotoxic.

Since addition of BHA did not block the death of cells treated with IFN- $\beta+$ dsRNA, we checked if caspases were activated in the process. DEVDase activity was clearly apparent in cells treated with anti-Fas, with and without BHA (Figure 6A). However, a strong increase in DEVDase activity occurred in cells treated with IFN- $\beta+$ dsRNA only if BHA was added (Figure 6A). Such BHA-dependent increase in activity was not observed with control cells or cells treated with TNF+LiCl, IFN or dsRNA. Western blot analysis showed that the extent of procaspase-9, procaspase- 3 and procaspase-7 processing in cells treated with IFN- $\beta+$ dsRNA+BHA was similar to that observed with antiFas (Figure 6B). Maximal caspase proteolysis in cells treated with IFN- $\beta+$ dsRNA+BHA was observed $3 \mathrm{~h}$ after dsRNA administration and coincided with the peak in cytosolic DEVDase activity (Figure 6A,B). 


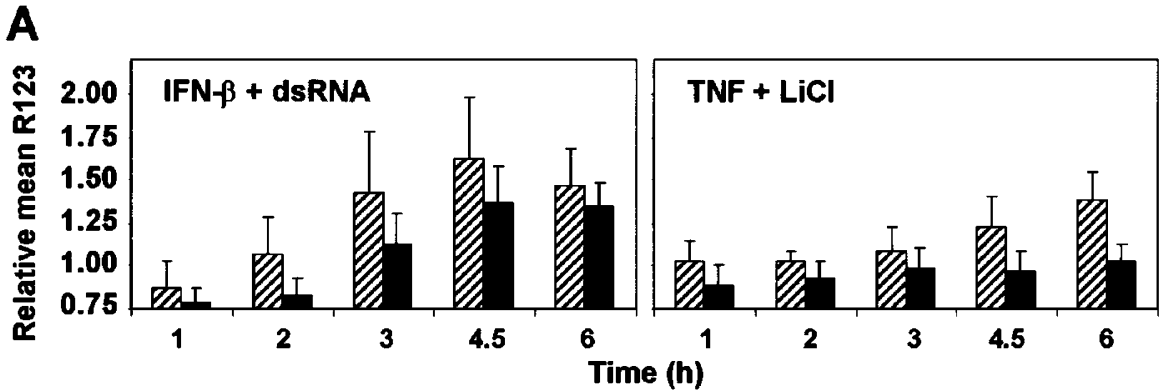

B

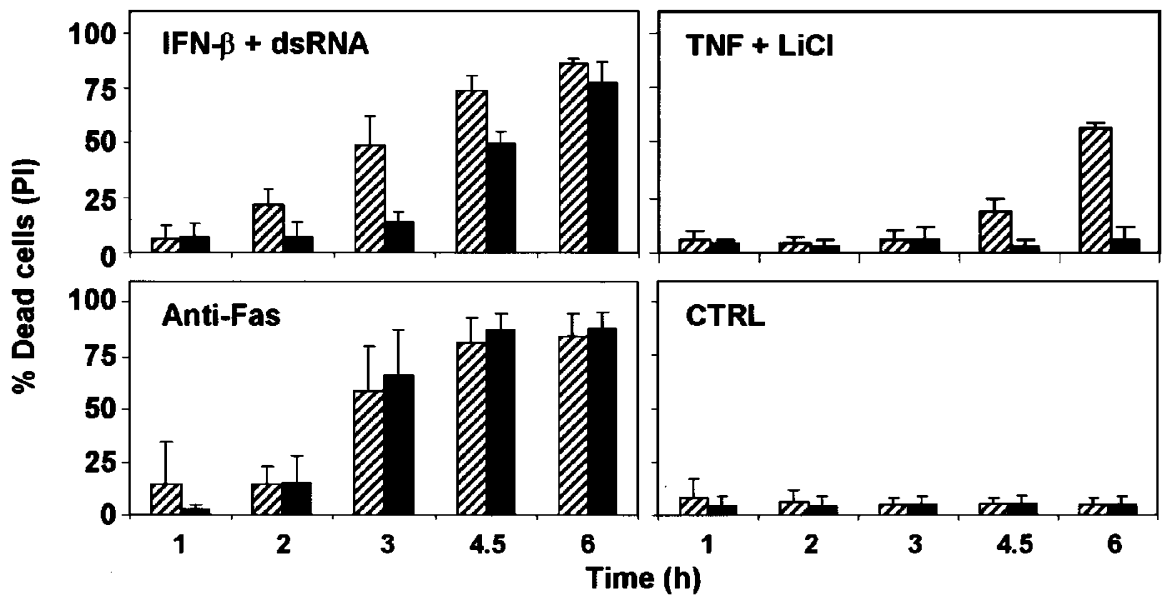

Figure 5 BHA decreases ROS production and delays loss of membrane integrity in cells treated with IFN- $\beta+$ dsRNA, or TNF+LiCl. L929sAFas cells were treated (filled bars) or not (dashed bars) with $100 \mu \mathrm{M} \mathrm{BHA}$ and analyzed by FACS. (A) Activation of ROS production in viable cells measured by conversion of DHR123 to R123. (B) Loss of membrane integrity as a measure for cell death determined as fractions stained by PI. Note that BHA inhibited TNF-induced cell death, but caused only a delay in cell death induced by IFN+dsRNA

Light microscopy revealed that addition of BHA shifted the death appearance of cells treated with IFN- $\beta+$ dsRNA from necrosis to apoptosis (Figure 7A). Side-scatter vs forward-scatter FACS analysis demonstrated that the different treatments resulted in a distinct shift in pattern of complete cell populations (Figure 7B). Necrosis correlated with an increase in side-scatter and a decrease in forwardscatter, whereas apoptosis (as observed after treatments with anti-Fas or IFN+dsRNA+BHA) led to a decrease in both parameters. Such an effect of BHA on cell morphology was not observed with control cells or cells treated with $\mathrm{TNF}, \mathrm{TNF}+\mathrm{LiCl}$, IFN or dsRNA. These results demonstrate that the presence of $\mathrm{BHA}$ can shift the response to a treatment with IFN+dsRNA from necrosis to apoptosis.

\section{Caspase inhibitors increase both ROS production and sensitivity to necrotic signals}

Inhibition of caspases, either by synthetic peptide inhibitors like zVAD-fmk or by overexpression of cytokine response modifier A (CrmA), leads to protection from apoptotic cell death in many cellular systems. ${ }^{46}$ In L929sA cells overexpression of CrmA leads to a dramatic increase in sensitivity to TNF-induced necrosis. Similarly, pretreatment with zVADfmk also sensitizes cells to TNF-induced necrosis and shifts the response to anti-Fas of L929sAFas cells from apoptosis to necrosis. ${ }^{30,31}$

We compared the effects of zVAD-fmk on cytotoxicity and ROS production in L929sAFas cells treated with antiFas, TNF or IFN- $\beta+$ dsRNA. Light microscopy showed that zVAD-fmk shifted the appearance of cells treated with antiFas from apoptosis to necrosis, and accelerated necrosis after a treatment with IFN- $\beta+$ dsRNA (Figure 7A). The whole cell population appeared to be affected, as clear from sidescatter vs forward-scatter FACS analysis (Figure 7B). The percentage of cells with necrotic appearance in populations exposed to TNF, IFN- $\beta$ +dsRNA or anti-Fas increased dramatically with ZVAD-fmk, but not in control cells treated with zVAD-fmk alone. Treatment with zVAD-fmk accelerated the response to TNF and IFN- $\beta+$ dsRNA, but not the response to anti-Fas (Figure $8 \mathrm{~A}$ ). Moreover, the inhibitor strongly increased ROS production in response to TNF or IFN- $\beta+$ dsRNA (Figure 8A).

DNA hypoploidy, a measure for degradation, was observed only in apoptosis mediated by Fas or induced by IFN- $\beta+$ dsRNA+BHA, and was clearly inhibited by zVADfmk (Figure 8B). Light microscopy confirmed that the morphology of cells dying in the presence of zVAD-fmk was necrotic, even if BHA was added (data not shown). Therefore, in addition to its ability to overcome apoptosis, 
A

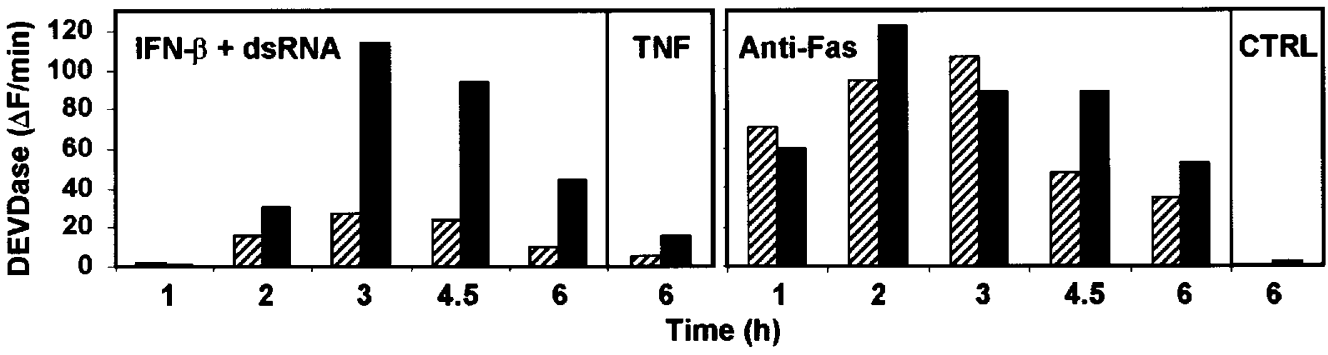

B

- BHA

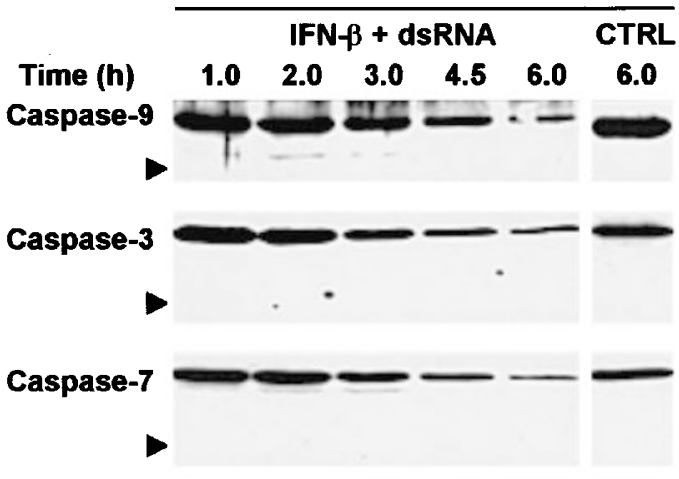

Anti-Fas
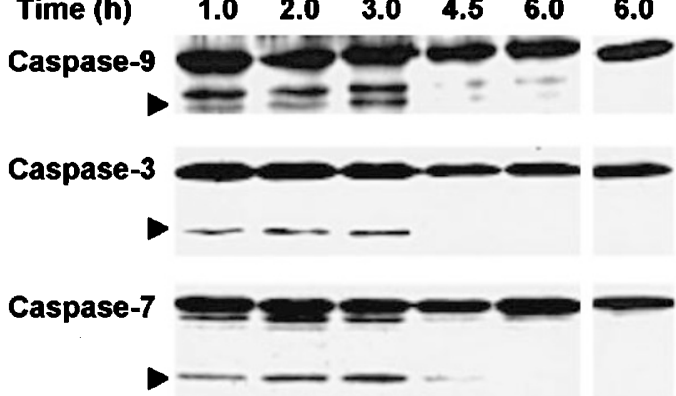

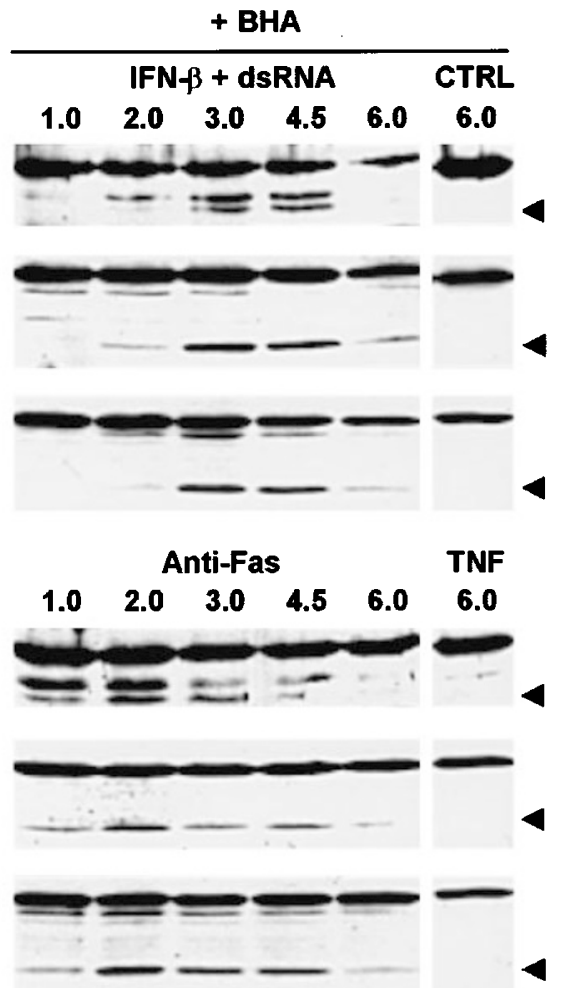

Figure 6 BHA shifts the response of L929sAFas cells to IFN- $\beta+$ dsRNA from necrosis to apoptosis. Cells were treated without BHA (dashed bars) or with $100 \mu$ M BHA (filled bars). At different time points after treatment, cells were collected and lysed. The soluble fraction was tested for caspase activity and processing. (A) Caspase activity measured by Ac-DEVD-amc cleavage. Note that IFN- $\beta+$ dsRNA induced caspase activation only when combined with BHA. (B) Western blots demonstrating that caspase-9, caspase-3 and caspase-7 are processed in cells treated with anti-Fas or IFN+dsRNA+BHA. Such caspase processing did not occur in cells treated with IFN+dsRNA without BHA, nor in cells treated with TNF+LiCl (TNF), nor in untreated controls (CTRL). Arrows indicate cleaved fragments

zVAD-fmk is capable of accelerating necrosis induced by IFN+dsRNA, suggesting that caspase activation is not required and on the contrary may be inhibitory for this cell death process.

\section{$\mathrm{Bcl}-2$ prevents BHA from shifting the response to IFN+dsRNA from necrosis to apoptosis}

$\mathrm{Bcl}-2$ overexpression was shown to protect cells from damage to the mitochondria and death induced by different cytotoxic compounds. ${ }^{47}$ Part of the beneficial effect of $\mathrm{Bcl}-2$ is correlated with the ability to prevent release of cytochrome $c^{26,48,49}$ We tested the effect of Bcl-2 on the cytotoxicity of IFN and dsRNA. Although Bcl-2 overexpression delayed the response to anti-Fas and decreased the level of caspase activation, cells still died by apoptosis (Figure 9A,B). Bcl-2 overexpression did not delay the necrotic response to IFN$\beta+$ dsRNA (Figure 9A). However, $\mathrm{Bcl}-2$ overexpression efficiently prevented activation of caspases in response to IFN- $\beta+$ dsRNA+BHA (Figure 9B), the morphology of dying cells being clearly necrotic (data not shown). This demonstrates that the apoptotic pathway induced by the presence of $\mathrm{BHA}$ in cells treated with IFN+dsRNA is completely suppressed by $\mathrm{Bcl}-2$ and suggests an involvement of mitochondrial cytochrome $c$ release.

Treatment with IFN+dsRNA did not lead to cytochrome $c$ release (Figure $9 \mathrm{C}$ ). However, addition of $\mathrm{BHA}$ resulted in release of cytochrome $c$ and proteolysis of procaspase- 9 , 
A
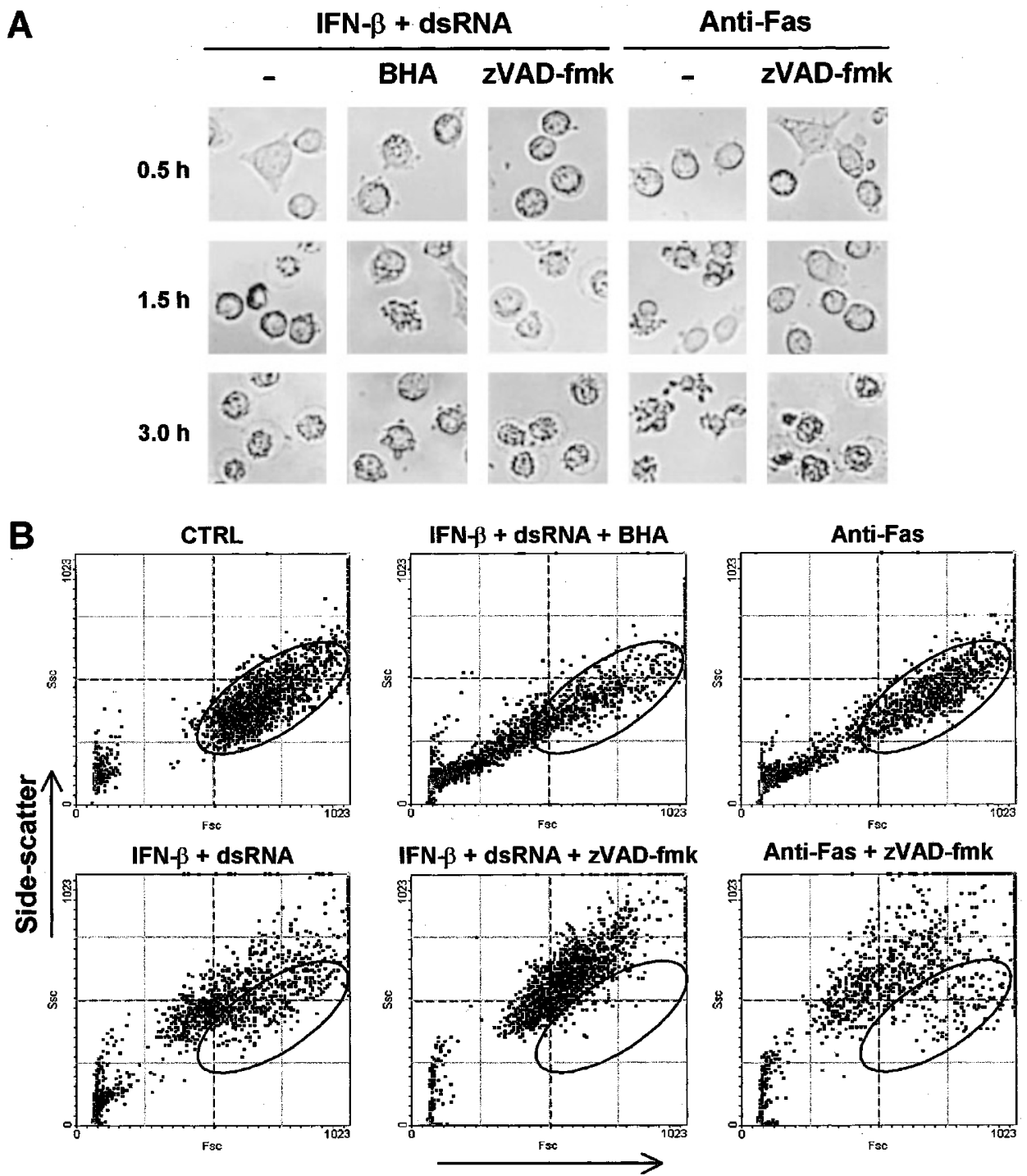

Forward-scatter

Figure 7 Effect of BHA and zVAD-fmk on the morphology of L929sAFas cell death. (A) Light microscopy of cells treated with IFN- $\beta+d s R N A$ or anti-Fas, without or with $100 \mu \mathrm{M} \mathrm{BHA}$, or $25 \mu \mathrm{M}$ zVAD-fmk. Note that BHA shifted the cell death morphology observed with IFN+dsRNA from necrosis to apoptosis, whereas the caspase inhibitor shifted the cell death pattern with anti-Fas treatment from apoptosis to necrosis. (B) Changes in cellular morphology of whole-cell populations as detected by side-scatter vs forward-scatter FACS analysis. Necrosis correlates with a small decrease in forward-scatter and an increase in side-scatter, whereas apoptosis leads to a strong decrease in both. BHA and ZVAD-fmk alone did not affect the cell morphology. Circled areas indicate the location of the control cell population

procaspase-3 and Bid. All of these events were prevented by $\mathrm{Bcl}-2$ overexpression (Figure $9 \mathrm{C}$ ), suggesting that the apoptotic process occurring in the presence of $\mathrm{BHA}$ is initiated by cytochrome $c$-dependent activation of caspase9, which in turn activates caspase-3 and caspase-7. Cleavage of Bid probably occurs downstream of the point of $\mathrm{Bcl}-2$ action and may be catalyzed by caspase-3. This results in a potential positive feedback loop, which amplifies release of cytochrome $c$ and thus the apoptotic process. Such a feedback loop was described previously for apoptosis induced by cytotoxic drugs and UV radiation. ${ }^{50-52}$ These results demonstrate that the shift induced from necrosis to apoptosis by BHA involves events in the mitochondria leading to release of cytochrome $C$.

\section{Discussion}

In this report we show that in addition to their known ability to protect cells from viral infections, type-I and type-II IFNs can sensitize cells to death induced by dsRNA. This cell death occurred rather rapidly, did not require de novo protein synthesis and hence was most probably not mediated by the induction of a DD receptor and its ligand. We show that treatment with dsRNA can lead to either apoptosis or necrosis, depending on the cellular context. In parental Jurkat cells dsRNA-induced death occurs by apoptosis. However, caspase-8 or FADD deficiency or inhibition of caspases with zVAD-fmk alter the response from apoptosis to necrosis. Nevertheless, cell death induced by IFN+dsRNA can be 
A

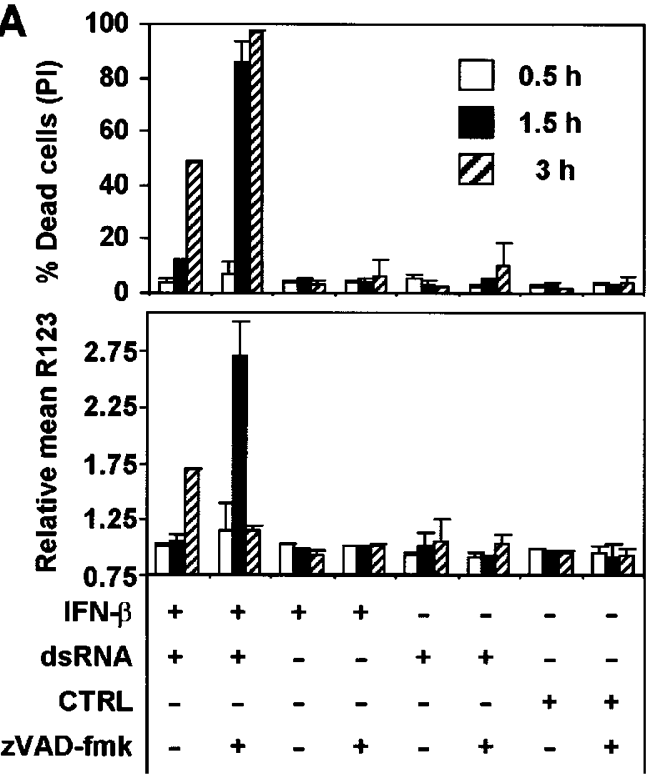

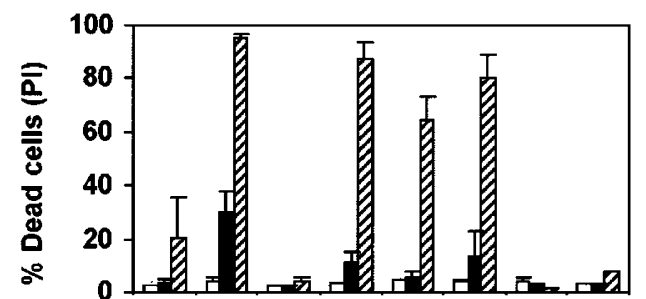

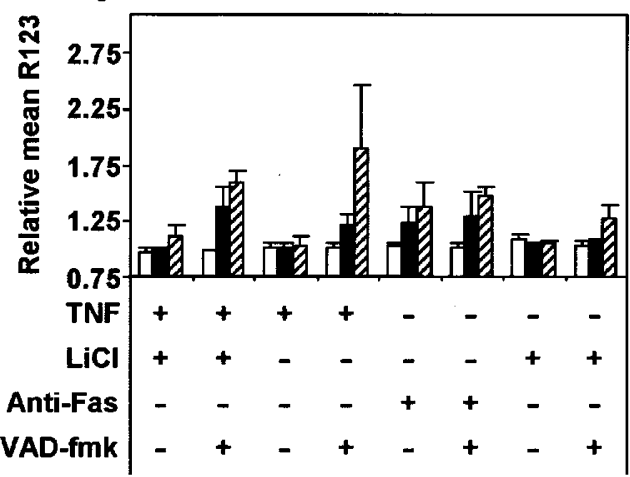

B
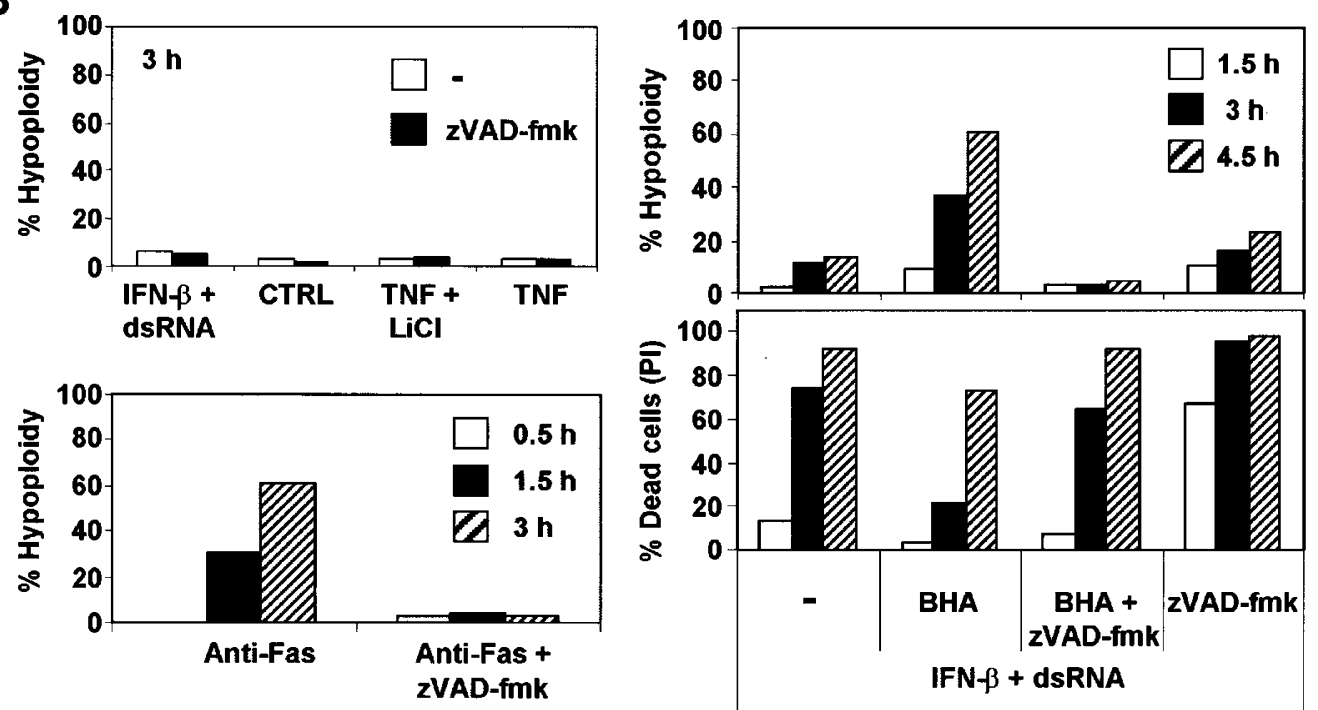

Figure 8 zVAD-fmk increases both ROS production and necrotic signaling in response to TNF and IFN+dsRNA, but blocks apoptosis. Cells were treated without or with $25 \mu \mathrm{M}$ zVAD-fmk and analyzed by FACS. (A) Upper panels, fractions of PI-positive cells as a measure for loss of membrane integrity and cell death; bottom panels, activation of ROS production in viable cells as measured by conversion of DHR123 to R123. (B) DNA degradation expressed as percentage of cells with hypoploid DNA levels measured by PI staining following freezing and thawing. Note that hypoploidy occurs under apoptotic conditions and is inhibited by zVAD-fmk

necrosis, even when the apoptotic machinery is present and functional, as observed with L929sAFas cells which respond to anti-Fas by apoptosis. These results suggest that caspase8 and FADD are not required for dsRNA-induced necrosis, although they may be needed for dsRNA-induced apoptosis. $^{12}$

Inhibition of hsp-90 can inhibit the mediation of necrosis by several DD receptors. ${ }^{34}$ Pretreatment with the hsp-90 inhibitor GA blocked dsRNA-induced necrosis, but not apoptosis. Inhibition of hsp-90 was reported to lead to the degradation of a large number of cellular proteins, many of which are enzymes playing a role in cell survival or death, such as Raf, MEK, FAK, PKR, nitric-oxide synthase, p53 and
RIP. ${ }^{53}$ Among these, PKR was suggested to be involved in dsRNA-induced apoptosis, ${ }^{10,12}$ and nitric-oxide synthase in dsRNA-induced necrosis. ${ }^{54,55}$ The DD-containing kinase RIP was shown to be required for apoptosis mediated by TNF receptor- $2^{42}$ and for DD receptor-mediated necrosis. ${ }^{34}$ Here we show that RIP-deficient cells are also resistant to IFN+dsRNA cytotoxicity, suggesting that RIP is required for initiation of both dsRNA-induced apoptosis and necrosis.

ROS production occurs in apoptotic cells. ${ }^{19,56}$ Its importance for death induction is, however, regarded to be higher in necrosis, since antioxidants such as BHA efficiently block this mode of cell death. ${ }^{18}$ We show that dsRNA-induced necrotic cell death involves high ROS 
A

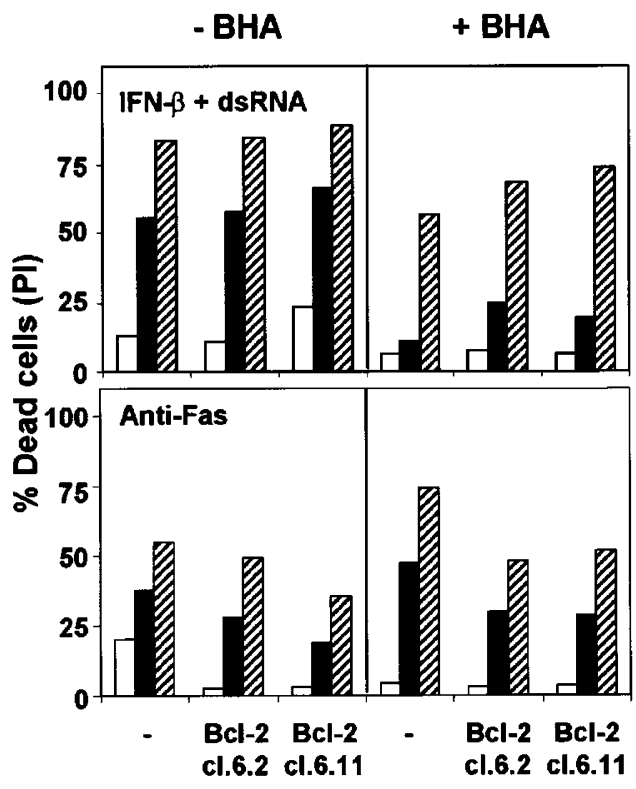

B

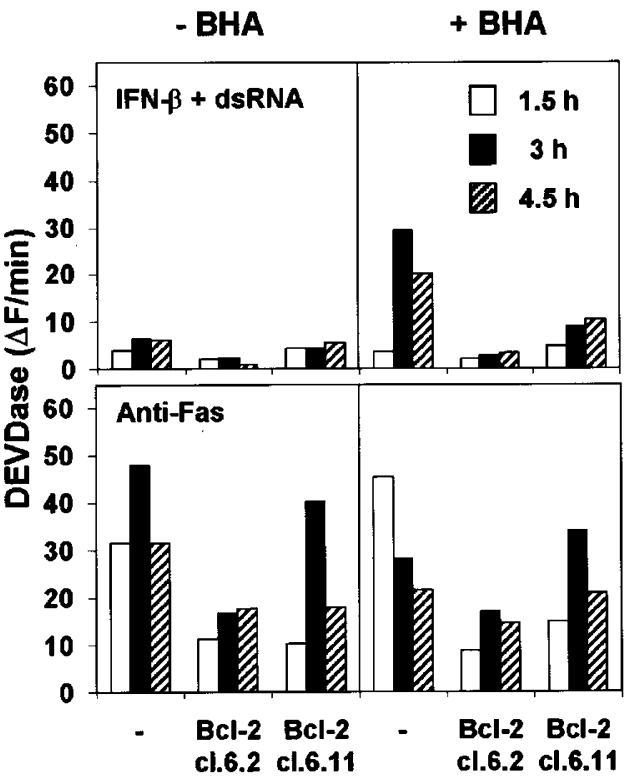

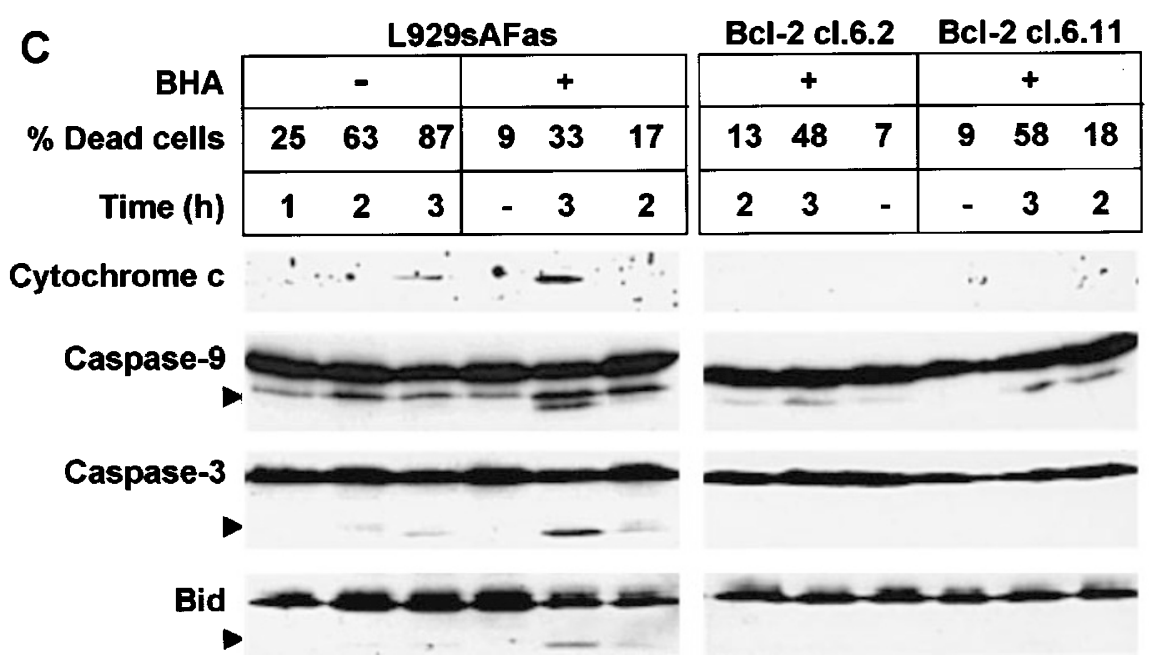

Figure $9 \mathrm{Bcl}-2$ prevents BHA from shifting the response to IFN+dsRNA from necrosis to apoptosis. Clones of L929sA cells were transfected with human Fas alone $(-)$ or with human $\mathrm{Bcl}-2$ (cl.6.2 and cl.6.11). Cells were treated without or with $100 \mu \mathrm{M} \mathrm{BHA}$. (A) Loss of membrane integrity and death measured as PI-positive cells. (B) Caspase activity as measured by Ac-DEVD-amc cleavage. Note that Bcl-2 overexpression inhibits caspase activation after treatment with IFN+dsRNA+BHA. (C) Western blots showing that Bcl-2 overexpression blocks release of cytochrome $c$, caspase-9 and caspase-3 activation, as well as Bid cleavage in cells treated with IFN+dsRNA+BHA. Arrows indicate cleaved fragments

production and is independent of endogenously expressed TNF, TNF receptors and activation of apoptotic caspases. In L929sAFAS, BHA inhibited TNF-induced necrosis, but not Fas-mediated apoptosis. ${ }^{30}$ BHA did not inhibit the cytotoxicity of IFN+dsRNA, but clearly shifted the response from necrosis to apoptosis. In addition, Bcl-2 overexpression itself delays the necrotic response of L929sAFAS cells to TNF, ${ }^{57}$ but not induction of necrosis by IFN+dsRNA. These results suggest that the pathway leading from TNF receptor-1 to necrosis is different from that initiated by dsRNA. Moreover, in Bcl-2-overexpressing L929sAFas.Bcl2 and JB6 cells, in which the mitochondrial apoptotic pathway is blocked, BHA did not block dsRNA-induced necrosis. Hence the necrotic stress was too high to overcome; possibly, mechanisms other than ROS production are leading to necrosis. On the other hand, inhibition of caspases by zVAD-fmk increased the production of ROS in response to either TNF or the combination of IFN and dsRNA, resulting in accelerated necrosis. Addition of zVAD-fmk blocked apoptosis induced by anti-Fas or the combination of IFN+dsRNA+BHA, and shifted the response from apoptosis to necrosis. Hence, caspases are not only needed for the apoptotic pathway, but they may also have a negative effect on necrosis and ROS production.

Mitochondria are a major target for $\mathrm{Bcl}-2$ protein family members, some of which (Bid, Bax or Bad) promote cell 
death, and others (Bcl-2 and $\left.\mathrm{Bcl}-\mathrm{X}_{\mathrm{L}}\right)$ usually delay it. ${ }^{26}$ Caspase-cleaved Bid targets mitochondria and leads to cytochrome $c$ release. Several reports demonstrated that caspase-8 activation, Bid cleavage and apoptosis in response to UV radiation are abrogated in cells overexpressing $\mathrm{Bcl}-2$ or $\mathrm{Bcl}-\mathrm{X}_{\mathrm{L}}$, whereas the response to Fas stimulation is only partially attenuated. ${ }^{50-52}$ These studies showed that cleavage of Bid during apoptosis induced by cytotoxic drugs and UV radiation occurs downstream of mitochondrial damage, is catalyzed by caspase- 3 and represents a feedback loop for amplification of apoptosisassociated mitochondrial cytochrome $c$ release. In our assays, $\mathrm{Bcl}-2$ overexpression retarded anti-Fas-induced apoptosis significantly, suggesting that the mitochondrial apoptotic pathway amplified the cellular response. However, $\mathrm{Bcl}-2$ overexpression completely blocked the shift from necrosis to apoptosis induced by the presence of $\mathrm{BHA}$ in cells treated with IFN+dsRNA, abolishing cytochrome $c$ release, caspase- 9 and caspase 3 activation, as well as cleavage of Bid. These results demonstrate that the shift to apoptosis induced in the presence of BHA starts in the mitochondria, indicating that a switch between the two death pathways can occur either at the level of the receptor complex ${ }^{30,32,34,35}$ or at the level of the mitochondria.

What is the physiological importance of dsRNA-induced apoptosis and necrosis? Both responses might play a role in innate and acquired immune responses. When a cell fails to overcome the propagation of a virus, it is to the benefit of the organism for the cell to die in the cleanest way, allowing destruction of all virus particles present. Apoptosis coupled to phagocytosis by macrophages was suggested to function in that way and to efficiently clear influenza $A$ virus. ${ }^{58}$ High cytoplasmic dsRNA contents may function as an internal signal initiating such a cell death program. However, many viruses encode for caspase inhibitors, such as baculovirus p35 or cowpoxvirus CrmA, which are exploited to prevent apoptotic suicide of the cellular host. $^{46,59}$ In such cases, the existence of another cell suicide program, either resistant to, or enhanced by, caspase inhibition, may be crucial for survival of the organism. The necrotic cell death pathway induced by IFNs and dsRNA, as the one described here, could fulfil such a function. Indeed, the explosion of the cell in what is called a lytic cycle, occurring in certain acute viral infections, might represent such a necrotic cell death. Moreover, in such cases the infected cell releases to the micro-environment infectious viral particles accompanied by immature unpacked viral material including dsRNA. Neighboring cells, which are also likely to become infected, may respond to this high load of dsRNA by either inflammatory cytokine production or cell death. In both cases the newly discovered dsRNA receptor TLR3 might be involved. Indeed, TLR3 signaling occurs through the DD-containing MyD88, ${ }^{7}$ a protein reported to recruit caspases by binding of FADD in response to bacterial infection and TLR2 activation, a process that also induces ROS production. ${ }^{60,61}$ Such a caspase activation pathway was also discovered in Drosophila, where Toll receptor activation can lead to recruitment of the caspase Dredd via binding of dFADD to dMyD88. ${ }^{62}$
The spilling out of the cellular contents in IFN- and dsRNA-induced necrosis might contribute to the development of autoimmunity and other pathologies. Insulindependent diabetes mellitus is a disease thought to result from autoimmune destruction of the insulin-producing $\beta$ cells in the pancreatic islets of Langerhans. Recently, several reports suggested that viral infection might induce diabetes even without direct infection of the pancreatic islets or induction of specific autoimmunity. ${ }^{63}$ Such virusinduced diabetes is suggested to occur due to inflammatory cytokines, and not perforin from autoreactive (antiviral) cytotoxic T-lymphocytes. ${ }^{64}$ The cytokines interleukin-1, TNF and IFN are cytotoxic to $\beta$-cells by inducing formation of oxygen-free radicals, nitric oxide, and peroxynitrite in the $\beta$ cells themselves. ${ }^{64,65}$ The effect of IFNs is intensified by dsRNA that can inhibit $\beta$-cell function and induce islet damage by its own. ${ }^{54,66}$ Interestingly, insulin-dependent diabetes mellitus was reported to occur also after treatment of viral hepatitis patients with exogenous IFNs. ${ }^{67,68}$ The identification of pathways and molecules involved in dsRNA-induced apoptosis and necrosis will hopefully lead to a better understanding of the role of this mode of cell death in immune responses and pathologies.

Finally, our results suggest that necrosis is not a passive and slow cell death process occurring only when apoptosis fails. They show that a given stimulus, be it anti-Fas or the combination of IFN and dsRNA, can lead to apoptosis or necrosis. The final outcome is a result of the interplay between pathways leading to either of the two death programs. The rapidity and the intensity of the response may decide how the cell will finally die. Inhibition of caspase recruitment and activation, or prevention of mitochondrial cytochrome $c$ release block apoptosis, and thus promote necrosis. On the other hand, inhibition of ROS production may block necrosis and allow apoptotic pathways to become apparent.

\section{Materials and Methods}

\section{Cell culture}

Caspase-8-deficient and Bcl2-overexpressing JB6 cells (donated by Dr. S Nagata and Dr. $H$ Matumura) were derived from Jurkat $E$ human T-cell lymphoma. ${ }^{29} \mathrm{JA} 3$, as well as caspase-8-deficient and FADDdeficient Jurkat clones were a gift from Dr. J Blenis. ${ }^{37,40}$ RIP-negative Jurkat and parental cells were obtained from Dr. B Seed. ${ }^{42}$ L929sA and L929r1 cells are derivatives of L929 murine fibrosarcoma cells. The first were selected for their sensitivity to TNF cytotoxicity, whereas the latter are negative for both TNF receptors and therefore TNFresistant. ${ }^{69,70}$ L929sA cells were transfected with the human Fas receptor cDNA with or without human $\mathrm{Bcl}-2 \mathrm{cDNA}$, resulting in L929sAFas and L929sAFas.Bcl-2 clones, respectively. ${ }^{30,57}$

\section{Antibodies, cytokines and reagents}

Recombinant murine TNF (specific biological activity of $2.2 \times 10^{8} \mathrm{IU} /$ $\mathrm{ml}$ ) was produced in $E$. coli and purified in our laboratory. Anti-human Fas antibody (anti-Fas, clone 2R2) was purchased from Cell Diagnostica (Munster, Germany). Recombinant murine IFN- $\alpha$ and recombinant human IFN- $\gamma$ were supplied by BioSource International 
(Camarillo, CA, USA). Recombinant human IFN- $\gamma$ was obtained from Roche Molecular Biochemicals (Basel, Switzerland). Recombinant murine IFN- $\gamma$ and IFN- $\beta$ were produced in $E$. coli and purified in our laboratory. Poly(I)-poly(C) (synthetic dsRNA) was dissolved at $3.5 \mathrm{mg} /$ $\mathrm{ml}$ in water (Amersham Pharmacia Biotech, Rainham, UK). GA (Sigma Chemical Co., St. Louis, MO, USA), dissolved at $100 \mathrm{mM}$ in DMSO, was used at $100 \mu \mathrm{M}$. BHA (Sigma Chemical Co.), dissolved at $100 \mathrm{mM}$ in ethanol, was used at $100 \mu \mathrm{M}$. PI (Becton Dickinson, Sunnyvale, CA, USA), dissolved at $3 \mathrm{mM}$ in PBS, was used at $30 \mu \mathrm{M}$. Dihydrorhodamine 123 (DHR123; Molecular Probes, Eugene, OR, USA), dissolved at $1 \mathrm{mM}$ in DMSO, was used at $0.1 \mathrm{M}$. The caspase peptide inhibitors zVAD-fmk and zDEVD-fmk were supplied by Bachem (Bubendorf, Switzerland). The caspase fluorogenic substrate acetyl-Asp(OMe)Glu(OMe)-Val-Asp(OMe)-aminomethylcoumarin (Ac-DEVD-amc) was obtained from Peptide Institute (Osaka, Japan). Rabbit anti-murine TNF antiserum was prepared in our laboratory. Antibodies to cytochrome $c$ and human Bcl-2 were from PharMingen (San Diego, CA, USA), and antibodies to human/mouse Bid from R\&D Systems (Minneapolis, MN, USA). Anti-murine caspase-9 antibodies were from New England Biolabs (Beverly, MA, USA). Rabbit polyclonal antibodies against recombinant murine caspase- 3 and caspase-7 were prepared at the Centre d'Economie Rurale (Laboratoire d'Hormonologie Animale, Marloie, Belgium).

\section{Cell survival assay}

L929 and Jurkat cells were seeded at $5 \times 10^{3}$ and at $2 \times 10^{4}$ cells per well, respectively, in 96-well plates. The next day cells were left untreated or were treated with IFNs; $24 \mathrm{~h}$ later dsRNA or anti-Fas were added. Cell survival was assessed $18 \mathrm{~h}$ later using 3-(4,5dimethylthiazol-2-yl)-2,5-diphenyltetrazolium bromide. ${ }^{71}$ The percentage of cell death was calculated using the equation $100 \% \times$ $\left(1-\left(A_{595 / 655}\right.\right.$-treated cells $-A_{595 / 655}$ medium $) /\left(A_{595 / 655}\right.$-untreated cells $-A_{595 / 655}$ medium).

\section{Induction of cell death in Jurkat cells for measuring DEVDase activity}

Jurkat cells seeded at $5 \times 10^{5}$ cells $/ \mathrm{ml}$ were treated or not with IFN. After $24 \mathrm{~h}$, cells were treated or not with anti-Fas or dsRNA. The percentage of dead cells was monitored by trypan blue exclusion after addition of anti-Fas or dsRNA. Cells were collected by centrifugation and assayed for DEVDase activity.

\section{Induction of cell death in L929 cells for FACS analysis, DEVDase activity measurement and Western blotting}

For flow fluorocytometric analysis, L929sAFas or L929sAFas.Bcl2 cells were seeded at $10^{5}$ cells $/ \mathrm{ml} /$ well and kept in suspension in uncoated 24-well tissue culture plates (Sarstedt, Newton, NC, USA) in serum-containing DMEM. Following 24-h culture, cells were treated with or without IFN- $\beta(200 \mathrm{IU} / \mathrm{ml})$. TNF $(10000 \mathrm{IU} / \mathrm{ml})$, with or without $10 \mathrm{mM} \mathrm{LiCl}$ or anti-Fas $(100 \mathrm{ng} / \mathrm{ml})$ or dsRNA $(100 \mu \mathrm{g} / \mathrm{ml})$ or medium as control, were added to the cells after $24 \mathrm{~h}$. In each experiment three replicate plates were prepared and used for FACS analysis, determination of DEVDase activity and Western blotting.

\section{FACS analysis}

Cells were harvested and kept on ice before analysis with a FACScalibur flow cytometer (Becton Dickinson). Changes in cellular morphology were determined by plotting side-scatter vs forward- scatter. Loss of cell membrane integrity as a measure of cell death was determined by $\mathrm{PI}$ fluorescence. ${ }^{30}$ DNA degradation was measured by PI staining after one freeze/thaw cycle to permeabilize cells, and was determined as the percentage of cells containing hypoploid DNA. ${ }^{30}$ Production of reactive oxygen species (ROS) was measured at $525 \mathrm{~nm}$ as mean rhodamine 123 (R123) fluorescence, resulting from DHR123 oxidation by intact cells. Cells were incubated with DHR123 for $30 \mathrm{~min}$ before analysis. Relative R123 was defined as the ratio of fluorescence emitted at a given time point and that of initial control.

\section{DEVDase activity}

The fluorogenic substrate assay for caspase activity was carried out as described previously. ${ }^{30}$ Cells were transferred to Eppendorf tubes, washed in cold phosphate buffer and lysed in $100 \mu$ l caspase lysis buffer, Cell debris was removed by centrifugation and caspase activity was determined by incubating $25 \mu \mathrm{l}$ of the soluble fraction with $50 \mu \mathrm{M}$ Ac-DEVD-amc in $150 \mu \mathrm{l}$ cell-free system buffer, containing $220 \mathrm{mM}$ mannitol, $68 \mathrm{mM}$ sucrose, $2 \mathrm{mM} \mathrm{MgCl} 2,2 \mathrm{mM} \mathrm{NaCl}, 2.5 \mathrm{mM} \mathrm{PO}_{4} \mathrm{H}_{2} \mathrm{~K}$, $0.5 \mathrm{mM}$ EGTA, $0.5 \mathrm{mM}$ sodium pyruvate, $0.5 \mathrm{mM}$ L-glutamine, $10 \mathrm{mM}$ HEPES- $\mathrm{NaOH} \mathrm{pH} 7.4$, and $10 \mathrm{mM}$ dithiothreitol. The release of fluorescent 7-amino-4-methylcoumarin was measured for $60 \mathrm{~min}$ at 2-min intervals by fluorometry (excitation at $360 \mathrm{~nm}$ and emission at 480 nm) (Cytofluor; PerSeptive Biosystems, Cambridge, MA, USA); the maximal rate of increase in fluorescence was calculated $(\Delta \mathrm{F} / \mathrm{min})$.

\section{Western blot analysis}

Cell lysate supernatants used for measuring DEVDase activity were also analyzed by Western blotting for detection of caspase and Bid proteolysis. Cells form each well analyzed for cytochrome $c$ release were washed in cold phosphate buffer and permeabilized with $100 \mu \mathrm{l}$ $0.02 \%$ digitonin dissolved in cell-free system buffer and left on ice for $1 \mathrm{~min}$. This treatment allows selective lysis of the plasma membrane without affecting the organelle membranes. The pellet (organelle fraction) was dissolved separately in Laemmli buffer. Samples were analyzed by $15 \%$ SDS-PAGE and Western blotting using antibodies to cytochrome $c$, Bid, caspase-9, caspase-3 and caspase-7, and developed with Enhanced Luminol reagent (Du Pont, Wilmington, DE, USA).

\section{Acknowledgments}

This work was supported by the Interuniversitaire Attractiepolen, the Fonds voor Wetenschappelijk Onderzoek-Vlaanderen (grants 31.5189 .00 and 3G.0006.01) and the EC-RTD (grant QLRT-CT-1999-00739). The authors thank $E$ Van Damme for technical assistance, and $A$ Raeymaekers, F Duerinck and E Decoster for preparing TNF, IFN- $\beta$, IFN- $\gamma$ and anti-TNF antibody. They are indebted to Dr. S Nagata and Dr. $\mathrm{H}$ Matumura (Department of Genetics, Osaka University Medical School, Suita, Japan), Dr. J Blenis (Department of Cell Biology, Harvard Medical School, Boston, MA) and Dr. B Seed (Department of Molecular Biology, Massachusetts General Hospital, Boston, MA) for donating various Jurkat cell lines.

\section{References}

1. Stark GR, Kerr IM, Williams BR, Silverman RH and Schreiber RD (1998) How cells respond to interferons. Annu. Rev. Biochem. 67: 227-264

2. Guidotti LG and Chisari FV (2001) Noncytolytic control of viral infections by the innate and adaptive immune response. Annu. Rev. Immunol. 19: 65-91 
3. Jacobs BL and Langland JO (1996) When two strands are better than one: the mediators and modulators of the cellular responses to double-stranded RNA. Virology 219: 339-349

4. Chu WM, Ostertag D, Li ZW, Chang L, Chen Y, Hu Y, Williams B, Perrault J and Karin M (1999) JNK2 and IKK $\beta$ are required for activating the innate response to viral infection. Immunity 11: $721-731$

5. Restifo NP (2000) Building better vaccines: how apoptotic cell death can induce inflammation and activate innate and adaptive immunity. Curr. Opin. Immunol. 12: $597-603$

6. Taylor-Papadimitriou $\mathrm{J}$ and Kallos $\mathrm{J}$ (1973) Induction of interferon by 'Sepharose'-bound poly(I)-poly(C). Nat. New Biol. 245: 143-144

7. Alexopoulou L, Holt AC, Medzhitov R and Flavell RA (2001) Recognition of double-stranded RNA and activation of NF- $\kappa$ B by Toll-like receptor 3. Nature 413: $732-738$

8. BachnerL, DeClercq E and Thang MN (1975) Sepharose-boundpoly (I)-poly (C): interaction with cells and interferon production. Biochem. Biophys. Res. Commun. 63: 476-483

9. Cooper JA, Morser J, Colby MS and Burke DC (1979) The toxic effect of doublestranded RNA for interferon-treated cells: evidence for a heterogeneous cellular response and the role of the cell nucleus. J. Gen. Virol. 43: 553-561

10. Balachandran S, Kim CN, Yeh WC, Mak TW, Bhalla K and Barber GN (1998) Activation of the dsRNA-dependent protein kinase, PKR, induces apoptosis through FADD-mediated death signaling. EMBO J. 17: 6888-6902

11. Tanaka N, Sato M, Lamphier MS, Nozawa H, Oda E, Noguchi S, Schreiber RD, Tsujimoto Y and Taniguchi T (1998) Type I interferons are essential mediators of apoptotic death in virally infected cells. Genes Cells 3: 29-37

12. Balachandran S, Roberts PC, Kipperman T, Bhalla KN, Compans RW, Archer DR and Barber GN (2000) Alpha/beta interferons potentiate virus-induced apoptosis through activation of the FADD/caspase-8 death signaling pathway. J. Virol. 74: 1513-1523

13. Castelli JC, Hassel BA, Wood KA, Li XL, Amemiya K, Dalakas MC, Torrence PF and Youle RJ (1997) A study of the interferon antiviral mechanism: apoptosis activation by the 2-5A system. J. Exp. Med. 186: 967-972

14. Der SD, Yang YL, Weissmann C and Williams BR (1997) A double-stranded RNA-activated protein kinase-dependent pathway mediating stress-induced apoptosis. Proc. Natl. Acad. Sci. USA 94: 3279-3283

15. Diaz-Guerra M, Rivas $C$ and Esteban M (1997) Activation of the IFN-inducible enzyme RNase L causes apoptosis of animal cells. Virology 236: $354-363$

16. Masutani $H(2000)$ Oxidative stress response and signaling in hematological malignancies and HIV infection. Int. J. Hematol. 71: 25-32

17. Goossens V, Grooten J, De Vos K and Fiers W (1995) Direct evidence for tumor necrosis factor-induced mitochondrial reactive oxygen intermediates and their involvement in cytotoxicity. Proc. Natl. Acad. Sci. USA 92: 8115-8119

18. Fiers W, BeyaertR, Declercq Wand VandenabeeleP (1999) More than one way to die: apoptosis, necrosis and reactive oxygen damage. Oncogene 18:7719-7730

19. Simon HU, Haj-Yehia A and Levi-Schaffer $F$ (2000) Role of reactive oxygen species (ROS) in apoptosis induction. Apoptosis 5: 415-418

20. Fadok VA, Bratton DL, Konowal A, Freed PW, Westcott JY and Henson PM (1998) Macrophages that have ingested apoptotic cells in vitro inhibit proinflammatory cytokine production through autocrine/paracrine mechanisms involving TGF- $\beta$, PGE2, and PAF. J. Clin. Invest. 101: 890-898

21. Takahashi $A$ (1999) Caspase: executioner and undertaker of apoptosis. Int. J. Hematol. 70: 226-232

22. Rathmell JC and Thompson CB (1999) The central effectors of cell death in the immune system. Annu. Rev. Immunol. 17: 781-828

23. Green DR and Beere HM (2000) Apoptosis. Gone but not forgotten. Nature 405: $85-90$

24. Reed CJ (2000) Apoptosis and cancer: strategies for integrating programmed cell death. Semin. Hematol. 37: 9-16

25. Skulachev VP (1999) Mitochondrial physiology and pathology; concepts of programmed death of organelles, cells and organisms. Mol. Aspects Med. 20: $139-184$

26. Desagher S and Martinou JC (2000) Mitochondria as the central control point of apoptosis. Trends Cell Biol. 10: 369-377

27. Chautan M, Chazal G, Cecconi F, Gruss P and Golstein P (1999) Interdigital cell death can occur through a necrotic and caspase-independent pathway. Curr. Biol. 9: $967-970$

28. Kitanaka C and Kuchino Y (1999) Caspase-independent programmed cell death with necrotic morphology. Cell Death Differ. 6: 508-515
29. Kawahara A, Ohsawa $Y$, Matsumura H, Uchiyama $Y$ and Nagata S (1998) Caspase-independent cell killing by Fas-associated protein with death domain. J. Cell Biol. 143: 1353-1360

30. Vercammen D, Brouckaert G, Denecker G, Van de Craen M, Declercq W, Fiers W and Vandenabeele $P$ (1998) Dual signaling of the Fas receptor: initiation of both apoptotic and necrotic cell death pathways. J. Exp. Med. 188: 919-930

31. Vercammen D, Beyaert R, Denecker G, Goossens V, Van Loo G, Declercq W, Grooten J, Fiers W and Vandenabeele P (1998) Inhibition of caspases increases the sensitivity of $L 929$ cells to necrosis mediated by tumor necrosis factor. J. Exp. Med. 187: 1477-1485

32. Khwaja A and Tatton L (1999) Resistance to the cytotoxic effects of tumor necrosis factor- $\alpha$ can be overcome by inhibition of a FADD/caspase-dependent signaling pathway. J. Biol. Chem. 274: 36817-36823

33. Boone E, Vanden Berghe T, Van Loo G, De Wilde G, De Wael N, Vercammen D, Fiers W, Haegeman G and Vandenabeele P (2000) Structure/function analysis of p55 tumor necrosis factor receptor and Fas-associated death domain. Effect on necrosis in L929sA cells. J. Biol. Chem. 275: 37596-37603

34. Holler N, Zaru R, Micheau O, Thome M, Attinger A, Valitutti S, Bodmer JL, Schneider P, Seed B and TschoppJ (2000) Fas triggers an alternative, caspase8-independent cell death pathway using the kinase RIP as effector molecule. Nat. Immunol. 1: 489-495

35. Luschen S, Ussat S, Scherer G, Kabelitz D and Adam-Klages S (2000) Sensitization to death receptor cytotoxicity by inhibition of fas-associated death domain protein (FADD)/caspase signaling. Requirement of cell cycle progression. J. Biol. Chem. 275: 24670-24678

36. Matsumura H, Shimizu Y, Ohsawa Y, Kawahara A, Uchiyama $Y$ and Nagata $S$ (2000) Necrotic death pathway in Fas receptor signaling. J. Cell Biol. 151: 1247 1256

37. Juo P, Woo MS, Kuo CJ, Signorelli P, Biemann HP, Hannun YA and Blenis J (1999)FADD is required for multiple signaling events downstream of the receptor Fas. Cell Growth Differ. 10: 797-804

38. Bodmer JL, Holler N, Reynard S, Vinciguerra P, Schneider P, Juo P, Blenis J and Tschopp J (2000) TRAIL receptor-2 signals apoptosis through FADD and caspase-8. Nat. Cell Biol. 2: 241-243

39. Sprick MR, Weigand MA, Rieser E, Rauch CT, Juo P, Blenis J, Krammer PH and Walczak H (2000) FADD/MORT1 and caspase-8 are recruited to TRAIL receptors 1 and 2 and are essential for apoptosis mediated by TRAIL receptor 2 . Immunity 12: 599-609

40. Juo P, Kuo CJ, Yuan J and Blenis J (1998) Essential requirement for caspase-8/ FLICE in the initiation of the Fas- induced apoptotic cascade. Curr. Biol. 8: 1001 1008

41. Lewis J, Devin A, Miller A, Lin Y, Rodriguez Y, Neckers L and Liu ZG (2000) Disruption of hsp90 function results in degradation of the death domain kinase, receptor-interacting protein (RIP), and blockage of tumor necrosis factorinduced nuclear factor- $\kappa$ B activation. J. Biol. Chem. 275: 10519-10526

42. Pimentel-Muinos FX and Seed B (1999) Regulated commitment of TNF receptor signaling: a molecular switch for death or activation. Immunity 11: 783-793

43. Kaser A, Nagata $S$ and Tilg $H$ (1999) Interferon $\alpha$ augments activation-induced $T$ cell death by upregulation of Fas (CD95/APO-1) and Fas ligand expression. Cytokine 11: $736-743$

44. Barber GN (2000) The interferons and cell death: guardians of the cell or accomplices of apoptosis? Semin. Cancer Biol. 10: 103-111

45. Beyaert R, Vanhaesebroeck B, Suffys P, Van Roy F and Fiers W (1989) Lithium chloride potentiates tumor necrosis factor-mediated cytotoxicity in vitro and in vivo. Proc. Natl. Acad. Sci. USA 86: 9494-9498

46. Ekert PG, Silke J and Vaux DL (1999) Caspase inhibitors. Cell Death Differ. 6: $1081-1086$

47. Kawahara A, Kobayashi T and Nagata S (1998) Inhibition of Fas-induced apoptosis by Bcl-2. Oncogene 17: 2549-2554

48. Allen RT, Cluck MW and Agrawal DK (1998) Mechanisms controlling cellular suicide: role of Bcl-2 and caspases. Cell. Mol. Life Sci. 54: 427-445

49. Ichimiya M, Chang SH, Liu H, Berezesky IK, Trump BF and Amstad PA (1998) Effect of $\mathrm{Bcl}-2$ on oxidant-induced cell death and intracellular $\mathrm{Ca}^{2+}$ mobilization. Am. J. Physiol. 275: C832-839

50. Gross A, Yin XM, Wang K, Wei MC, Jockel J, Milliman C, Erdjument-Bromage $H$, Tempst $P$ and Korsmeyer SJ (1999) Caspase cleaved BID targets mitochondria and is required for cytochrome $c$ release, while $B C L-X_{L}$ prevents this release but not tumor necrosis factor-R1/Fas death. J. Biol. Chem. 274: 1156-1163 
51. Belka C, RudnerJ, Wesselborg S, Stepczynska A, Marini P, Lepple-Wienhues A Faltin H, Bamberg M, Budach W and Schulze-Osthoff K (2000) Differential role of caspase-8 and BID activation during radiation- and CD95-induced apoptosis. Oncogene 19: $1181-1190$

52. Slee EA, Keogh SA and Martin SJ (2000) Cleavage of BID during cytotoxic drug and UV radiation-induced apoptosis occurs downstream of the point of Bcl-2 action and is catalysed by caspase-3: a potential feedback loop for amplification of apoptosis-associated mitochondrial cytochrome c release. Cell Death Differ. 7: $556-565$

53. Richter Kand Buchner J (2001) Hsp90: chaperoning signal transduction. J. Cell. Physiol. 188: 281-290

54. Heitmeier MR, Scarim AL and Corbett JA (1999) Double-stranded RNA inhibits $\beta$-cell function and induces islet damage by stimulating $\beta$-cell production of nitric oxide. J. Biol. Chem. 274: 12531-12536

55. Scarim AL, Arnush M, Blair LA, Concepcion J, Heitmeier MR, Scheuner D, Kaufman RJ, Ryerse J, Buller RM and CorbettJA (2001) Mechanisms of beta-cell death in response to double-stranded (ds) RNA and interferon-gamma: dsRNAdependent protein kinase apoptosis and nitric oxide-dependent necrosis. Am. J Pathol. 159: 273-283

56. Sidoti-de Fraisse C, Rincheval V, Risler Y, Mignotte B and Vayssière JL (1998) TNF- $\beta$ activates at least two apoptotic signaling cascades. Oncogene 17:16391651

57. Denecker G, Vercammen D, Steemans M, Vanden Berghe T, Brouckaert G, Van Loo G, Zhivotovsky B, Fiers W, Grooten J, Declercq W and Vandenabeele P (2001) Death receptor-induced apoptotic and necrotic cell death: Differential role of caspases and mitochondria. Cell Death Differ. 8: 829-840

58. Fujimoto I, Pan J, Takizawa T and Nakanishi Y (2000) Virus clearance through apoptosis-dependent phagocytosis of influenza A virus-infected cells by macrophages. J. Virol. 74: 3399-3403

59. Everett $H$ and McFadden $G$ (1999) Apoptosis: an innate immune response to virus infection. Trends Microbiol. 7: 160-165

60. Aliprantis AO, Yang RB, Weiss DS, Godowski P and Zychlinsky A (2000) The apoptotic signaling pathway activated by Toll-like receptor-2. EMBO J. 19: $3325-3336$
61. Aliprantis AO, Weiss DS and Zychlinsky A (2001) Toll-like receptor-2 transduces signals for NF- $\kappa$ B activation, apoptosis and reactive oxygen species production. J. Endotoxin Res. 7: 287-291

62. Horng T and Medzhitov R (2001) Drosophila MyD88 is an adapter in the Toll signaling pathway. Proc. Natl. Acad. Sci. USA 98: 12654-12658

63. Sarukhan A, Lechner $O$ and von Boehmer H (1999) Autoimmune insulitis and diabetes in the absence of antigen-specific contact between T cells and islet $\beta$ cells. Eur. J. Immunol. 29: 3410-3416

64. Seewaldt S, Thomas HE, Ejrnaes M, Christen U, Wolfe T, Rodrigo E, Coon B, Michelsen B, Kay TW and von Herrath MG (2000) Virus-induced autoimmune diabetes: most $\beta$-cells die through inflammatory cytokines and not perforin from autoreactive (anti-viral) cytotoxic T-lymphocytes. Diabetes 49: 1801-1809

65. Rabinovitch A and Suarez-Pinzon WL (1998) Cytokines and their roles in pancreatic islet $\beta$-cell destruction and insulin-dependent diabetes mellitus. Biochem. Pharmacol. 55: 1139-1149

66. Blair LA, Heitmeier MR, Scarim AL, Maggi Jr. LB and Corbett JA (2001) Doublestranded RNA-dependent protein kinase is not required for double-stranded RNA-induced nitric oxide synthase expression or nuclear factor- $\kappa$ B activation by islets. Diabetes 50: 283-290

67. Fabris P, Betterle C, Greggio NA, Zanchetta R, Bosi E, Biasin MR and de Lalla F (1998) Insulin-dependent diabetes mellitus during $\alpha$-interferon therapy for chronic viral hepatitis. J. Hepatol. 28: 514-517

68. Hayashi T, Morimoto M, Iwata H and Onodera T (1998) Interferon- $\gamma$ plays a role in pancreatic islet-cell destruction of reovirus type 2-induced diabetes-like syndrome in DBA/1 suckling mice. Int. J. Exp. Pathol. 79: 313-320

69. VanhaesebroeckB, Van Bladel S, Lenaerts A, Suffys P, Beyaert R, Lucas R, Van Roy F and Fiers W (1991) Two discrete types of tumor necrosis factor-resistant cells derived from the same cell line. Cancer Res. 51: 2469-2477

70. Vanhaesebroeck B, Decoster E, Van Ostade X, Van Bladel S, Lenaerts A, Van Roy $F$ and Fiers W (1992) Expression of an exogenous tumor necrosis factor (TNF) gene in TNF-sensitive cell lines confers resistance to TNF-mediated cell lysis. J. Immunol. 148: 2785-2794

71. TadaH, Shiho O, Kuroshima K, Koyama Mand Tsukamoto K(1986) An improved colorimetric assay for interleukin 2. J. Immunol. Methods 93: 157-165 